\title{
Mantle earthquakes beneath the South Iberia continental margin and Gulf of Cadiz - constraints from an onshore-offshore seismological network
}

\author{
Ingo Grevemeyer ${ }^{1}$, Luis Matias ${ }^{2}$, and Sonia Silva ${ }^{2}$ \\ ${ }^{1}$ GEOMAR Helmholtz Centre of Ocean Research, Wischhofstrasse 1-3, 24148 Kiel, Germany (igrevemeyer@geomar.de) \\ ${ }^{2}$ Instituto Dom Luiz, Faculdade de Ciências, Universidade de, Lisboa, Portugal
}

\begin{abstract}
The Gulf of Cadiz and the passive continental margin of southern Iberia to the west of the Strait of Gibraltar locally accommodate the presently ongoing convergence between Africa and Eurasia by widespread, rather diffusive, seismic activity. Seismicity of the northern Gulf of Cadiz was derived from an amphibious seismological network, including 24 temporary marine offshore stations, besides the permanent networks in Portugal, Spain, and Morocco. During the 6 month of the offshore network operation, in total 86 local earthquakes were located at six or more offshore stations with the majority of earthquakes occurring to the southwest of Iberia and along the Algarve continental margin off southern Iberia. The distribution of events along the Algarve margin mimics features reported for the Atlantic passive continental margins of both South and North America. Focal mechanisms at the Portimão Bank support that seismically active areas are associated with compression. Similar stress patterns are reported for the east coast of South and North America. However, while earthquakes along the American east coast occur at crustal levels, earthquakes in the northern Gulf of Cadiz occur both in the lower crust and upper mantle, with the majority of events rupturing within the mantle, including a number of well-located earthquakes beneath crust forming the continent-ocean transition zone. The large number of earthquakes in the mantle might be caused by the unique geological setting, where deformation occurs in cool lithosphere of Mesozoic age. We suggest that seismicity along the Algarve margin is caused by re-activation of pre-existing marginparallel faults rather than corresponding to newly formed structures related to a new developing plate boundary.
\end{abstract}

\section{Key words:}

Earthquakes, Passive margins, Active deformation, Seismic hazard, Iberia, Gulf of Cadiz

\section{Introduction}

The ocean-continent boundary of southern Iberia to the west of the Strait of Gibraltar is defined as a passive continental margin, along which the continent and seafloor are part of the same plate (Figure 1). In the framework of plate tectonics (e.g., McKenzie and Parker, 1967; Morgan, 1968) the interior of plates is defined as being seismically inactive. However, even stable continental regions (SCR), including passive continental margins, show occasionally seismic activity. World-wide, Schulte and Mooney (2005) reported 1371 crustal earthquakes with magnitude larger than 4.5 hitting stable continental lithosphere, with roughly $50 \%$ of the seismicity occurring at Mesozoic passive margins. Earthquakes rupturing along passive margins occur both onshore and offshore and may reach magnitude 7 (Wolin et al., 2012). It is generally believed that these events are related to the reactivation of favourably oriented pre-existing fault planes in response to broad-scale uniform regional stress fields (Zoback, 1992; Wolin et al., 2012). This idea is supported by observation that passive margins are often reactivated in compression (Cloetingh et al., 2008). 
Wolin et al. (2012) called the Eastern US passive continental margin off Virginia "a passiveaggressive" margin after on $23^{\text {rd }}$ of August 2011 a magnitude $M=5.8$ hit the town of Mineral. The entire eastern coast of North American has a long record of several magnitude 6-7 earthquakes, including the $M=7.21929$ Grand Banks earthquake, causing a landslide and tsunami (Bent, 1995). In addition to far-field stresses, glacial isostatic rebound has been suggested to control earthquakes at passive margins. However, farther south along the margin of eastern Brazil earthquakes with magnitudes of larger than 5 occur every 20 to 25 years (Assumpcao et al., 2008), indicating that forces other than isostatic adjustments contribute to control seismicity along passive margins.

Passive continental margins occur generally several thousands of kilometres away from major plate boundary faults. The southern passive margin of Iberia, including the Algarve margin, however, is located near or at the Azores-Gibraltar seismic zone, marking the plate boundary between Eurasia/Iberia and Africa. To the east of $14^{\circ} \mathrm{W}$ the plate boundary is not well defined and seismicity is rather diffuse (Sartori et al., 1994; Buforn et al., 2004) and the WNW-ESE plate convergence of $\sim 4$ $\mathrm{mm} / \mathrm{yr}$ (DeMets et al., 2010) is accommodated through widespread tectonically active deformation (Sartori et al., 1994; Hayward et al., 1999). Consequently, convergence may have caused Neogene to Quaternary reactivation of Mesozoic rifting structures (Zitellini et al., 2004), which in turn may control tectonic and seismic activity along the passive margin of southern Iberia and in the Gulf of Cadiz (e.g., Borges et al., 2001; Buforn et al., 2004; Stich et al., 2005).

Bathymetric and multi-channel seismic (MCS) data suggest that today's plate boundary might be defined by a set of WNW-ESE trending faults (called the South-West Iberia Margin or SWIM faults; Zitellini et al., 2009; Bartolome et al., 2012), running to the south of $\sim 36^{\circ} \mathrm{N}$. In this scenario the seismicity paralleling the Algarve margin might not be related to a newly developing plate boundary, but still might be associated with far-field stresses caused by convergence. In a scenario of active westward retreat of a narrow slab (e.g., Gutscher, 2004; Gutscher et al., 2012) hanging under the western Alboran Sea and the southern Betics (Gutscher et al., 2002; García-Castellanos and Villaseñor, 2011) seismicity along the Algarve margin might be caused by a so called SubductionTransform Edge Propagator, or STEP fault (Govers and Wortel, 2005).

Here, we report results from a large amphibious seismic network, including 24 offshore oceanbottom-seismometers (OBS) installed in the Gulf of Cadiz to the north of $35^{\circ} 25^{\prime} \mathrm{N}$ and east of $9^{\circ} 30^{\prime} \mathrm{W}$ (Figures 1 and 2). The network allows robust source estimates of offshore seismicity and hence may yield constraints on the active deformation of crust und upper mantle of the reactivated Mesozoic passive margin and seismicity in the Gulf of Cadiz. Our interpretations are nurtured by a new seismic refraction and wide-angle profile shot in the area (Sallares et al., 2011) that provides robust estimates on the nature of crust underlying the Gulf of Cadiz sedimentary prism and the southern Iberian continental margin. We will discuss micro-earthquake activity in the Gulf of Cadiz with respect to different tectonic settings, including other passive continental margins like the east coast of both North and South America. However, seismicity might be controlled by a newly developing plate boundary and we will hence discuss features with respect to a reorientation of the EurasianAfrican plate boundary. Further, the seismicity pattern derived from the deployment will be discussed with respect to scenarios envisioning either active eastward dipping subduction (Gutscher et al. 2002) or active strike-slip faulting along the SWIM faults (e.g, Zitellini et al., 2009; Bartolome et al., 2012; Duarte et al., 2011). 


\section{Tectonic setting}

In the Gulf of Cadiz to the west of the Gibraltar Arc, the plate boundary between Eurasia and Africa is rather poorly defined. Instead, WNW-ESE plate convergence of $4 \mathrm{~mm} / \mathrm{yr}$ (DeMets et al., 2010) is accommodated over a wide and diffuse deformation zone (Sartori et al., 1994; Hayward et al., 1999), following a large scale strain partitioning scenario (Terrinha et al., 2009) and showing significant and widespread seismic activity (e.g., Stich et al., 2005; Buffon et al., 2004; Geissler et al., 2010). The region is also characterized by large earthquakes and tsunamis, such as the Great Lisbon earthquake of $1^{\text {st }}$ of November 1755 with an estimated magnitude of Mw 8.5-8.8 (Martinez-Solares et al., 1979; Johnston, 1996) and the $1969 \mathrm{Mw}=7.9$ Horseshoe Abyssal Plain earthquake (Fukao, 1973).

Crustal domains in the central Gulf of Cadiz and at the Mesozoic continental margin of the Algarve, Southern Portugal/Iberia, can be defined by seismic refraction and wide-angle data (Sallares et al., 2011; Martinez-Loriente et al., 2014; Figure 1), indicating 28-30 km thick continental crust near the coast line, a $60 \mathrm{~km}$ wide transition zone, where the crust thins to $\sim 20 \mathrm{~km}$, and a $7 \mathrm{~km}$ thick oceanic crust roughly 100-120 km off the coast (Figure 1). The passive margin of southern lberia and the Algarve formed during the Triassic breakup of Pangea (Heymann, 1989). However, oceanic crust flooring the Gulf of Cadiz postdates margin formation. Plate tectonic models (e.g., Schettino and Turco, 2011) suggests that between $185 \mathrm{Ma}$ and $145 \mathrm{Ma}$ rifting between Africa and North America opened the Atlantic while farther east the Tethys ocean formed. Plate motion caused by the opening of the Atlantic was transferred to the Tethyan realm through a system of transform faults between Iberia and Morocco. Sallares et al. (2011) suggested that oceanic crustal formation occurred at the end of the opening of the Tethys at $\sim 145 \mathrm{Ma}$, probably by oblique sinistral seafloor spreading which ceased when Newfoundland broke apart from Western Iberia at $\sim 130 \mathrm{Ma}$.

Plate reconstructions suggest that convergence between Africa and Eurasia started between 120 to $83 \mathrm{Ma}$. From the Paleocene to Eocene, African and Eurasian convergence was mostly accommodated in the Alpine collision zone. Since about $35 \mathrm{Ma}$ the western Mediterranean and the Gibraltar arc were affected by slab roll-back (Royden, 1993; Faccenna et al., 2001; Spakman and Wortel, 2004). Geodynamic modelling suggests that northward subduction occurred initially at the Balearic margin. At about $30 \mathrm{Ma}$, the trench and subduction rotated and westward slab roll-back occurred until Tortonian, suggesting that both subduction and slab roll back is stalled since $8 \mathrm{Ma}$ (Chertova et al., 2014).

Today, the main morphotectonic feature of the Gulf of Cadiz is the up to $10 \mathrm{~km}$ thick sedimentary wedge (e.g., Thiebot and Gutscher, 2006). Its formation is still controversially discussed. The wedge itself is formed by large allochthonous masses with seismically chaotic reflections at the forefront of the Gibraltar Arc (e.g., Torelli et al., 1997; Maldonado et al., 1999; Gràcia et al., 2003; Rovere et al.; 2004). The chaotic sedimentary melange shows signs of intense deformation and westward transport, attributed primarily to wrench faulting between Africa and Eurasia as well as gravity sliding (Torelli et al., 1997; Maldonado et al., 1999). However, the observed features can also be interpreted as accretionary complex of an eastward dipping subduction zone (e.g., Gutscher et al., 2002), supporting the tectonic framework introduced above. Miocene eastward subduction is supported by ample evidence, including arc-formation in the Alboran Sea (Duggen et al., 2003: 2004; Booth-Rea et al., 2007) and seismological imaging of a subducted slab and intermediate seismicity under the West Alboran Sea (Gutscher et al., 2002; García-Castellanos and Villaseñor, 2011; Grevemeyer et al., 2015) and mantle flow (Díaz and Gallart, 2014). Gutscher et al. (2006) suggested that still active subduction may have caused the Great Lisbon earthquake of 1755 . However, deformation pattern and geodynamic modelling may suggest that subduction is stalled since Tortonian (e.g., Iribarren et al., 2007; Chertova et al., 2014). 
Simulations of seismic ground motions of the Great Lisbon earthquake favour a source to the west of Cape Sao Vicente (Grandin et al., 2007) in the Horseshoe abyssal plain or at the Gorringe Bank (Johnston, 1996). Baptista et al. $(1998 ; 2011)$ analyzed all evidences on the 1755 tsunami and concluded that wave amplitudes and tsunami travel times estimated from historical records are best explained by a tectonic source in the SW of Iberia closer to the coast, excluding the Gorringe Bank and Gulf of Cadiz accretionary wedge as possible sources.

High-resolution bathymetric mapping of the Gulf of Cadiz and the adjacent Horseshoe abyssal plain indicated a set of almost linear and sub parallel dextral strike-slip faults, the South-West-lberiaMargin or SWIM faults (Zittelini et al., 2009). The features form a narrow band of deformation over a length of $600 \mathrm{~km}$ and roughly coincide with a small circle centred on the pole of rotation of Africa with respect to Eurasia. Zitellini et al. (2009) suggested that the SWIM faults may connect to the Eurasian-African plate boundary farther west and east and hence may indicate a newly developing segment of the plate boundary between Africa and Eurasia. Seismic reflection imaging revealed that the SWIM lineaments cut down to at least $10 \mathrm{~km}$ (Bartolome et al., 2012). Terrinha et al. (2009) and Duarte et al. (2011) suggest that the lineaments represent the reactivation of Mesocoic faults that root in the underlying basement. Seismically neither the SWIM lineaments nor the proposed Gulf of Cadiz subduction thrust showed any prominent seismic activity detectable utilizing onshore seismic monitoring (e.g., Buforn et al., 2004; Stich et al., 2005).

\section{Seismological data and methodology}

\subsection{Data}

In the Gulf of Cadiz 24 ocean-bottom-seismometers (OBS) were deployed along the southern Iberian continental margin and on the Gulf of Cadiz accretionary wedge (Figures 1 and 2). The deployment was part of the European Science Foundation (ESF) coordinated programme TOPO-Europe. Marine deployments of our exercise, called TOPO-MED, were supplemented by the permanent seismic networks operated in Portugal, Spain, and Morocco (Figure 2).

The offshore network was operated between $20^{\text {th }}$ of January 2010 and $21^{\text {st }}$ of July 2010 . The network consisted of 24 OBS, including 5 wide-band OBS operating a three-component Guralp CMG-40T (60 s) seismometer and a HighTech HTI-04-PCA/ULF hydrophone from the German DEPAS pool. In addition, 19 GEOMAR-OBS, equipped with a hydrophone and 3-compenent short-period seismometers with a natural frequency of $4.5 \mathrm{~Hz}$, were operated. Seismic events were detected automatically in the continuous OBS record using a short-term-average versus a long-term-average (STA/LTA) triggering approach. We used a STA window of $0.5 \mathrm{~s}$ and a LTA window of $60 \mathrm{~s}$. The trigger ratio was 4.0 and the de-trigger ratio was 2.5. The trigger parameters were applied to unfiltered vertical component data. We consider a trigger to be an earthquake when it was detected on six or more OBS stations. Visual inspection of the data suggested that we obtained generally less than $\sim 5 \%$ false triggers and lose only those events that were recorded on a few stations and characterized by a poor signal noise ratio, while all major events were included. Surprisingly, only a reasonable small number of $<100$ events was detected and the detected events generally coincide with earthquakes reported in the national catalogue of Portugal (Fernando Carrilho, pers. Communication, 2012). We believe that the up to 12 $\mathrm{km}$ thick sedimentary prism (Thiebot and Gutscher, 2006) caused a very high attenuation. Further, the area is inherently affected by strong noise caused by ship's traffic through the Strait of Gibraltar (Figure. 3), requiring earthquakes with magnitudes of larger $\sim 2$ to be detected within the offshore network. This interpretation is supported by the fact that the smallest magnitude of local 
earthquakes was roughly one order of magnitude larger than for an OBS network operated in the Alboran Sea to the east of Gibraltar (Grevemeyer et al., 2015). The OBS farthest to the east, sitting on the thickest portion of the prism, provided the smallest number of readings of local earthquakes, supporting the interpretation that thicker sediments provide higher attenuation. However, the OBS network detected all offshore events occurring within the network that were reported in either the catalogue of the Instituto Português do Mar e da Atmosfera (IPMA, Portugal) or the Spanish Instituto Geografico Nacional (IGN, Spain). In addition, four and six additional events were detected with respect to the IPMA and IGN catalogue, respectively.

All events were registered into a SEISAN database (Havskov and Ottemöller, 2000), using a 3 minutes long time window from the continuous OBS records and data from the Portuguese network, starting 20 seconds prior to trigger time. P-wave and S-wave arrival times were hand-picked. In total, we obtained 86 local earthquakes from the Gulf of Cadiz and adjacent domains. The reading weighting scheme ranges from factor 0 , corresponding to the lowest uncertainty $( \pm 0.05 \mathrm{~s})$, to factor $4(>0.3 \mathrm{~s})$ for doubtful readings that were not used. The total average $P$ wave reading error is estimated at $\pm 0.12 \mathrm{~s}$. Latter, additional onset times from land stations in Spain and Morocco were added to the database (http://www.isc.ac.uk/iscbulletin/search/bulletin).

\subsection{Location procedure and velocity models}

To constrain epicentres and focal depth we surveyed four different $1 \mathrm{D}$ velocity models and used two different algorithms. Earthquakes were located (1) with the program HYPOCENTER, which employs an iterative solution to the nonlinear localization problem (Lienert et al., 1986; Lienert and Havskov, 1995) and (2) using the non-linear probabilistic location procedure NonLinLoc of Lomax et al. (2000). Unfortunately, the number of events within the network was too small to derived robust station corrections. We therefore used for both location procedures station elevations to constrain differences in topography between onshore and offshore domains.

Locating earthquakes in the Gulf of Cadiz using a 1-D reference model is a difficult task since crustal thickness for onshore stations will be in the order of $30 \mathrm{~km}$ while OBS on the prism will sit on thin oceanic crust covered by 3 to $8 \mathrm{~km}$ of sediments. We therefore utilized different velocity models and location algorithms to provide an effective way to explore the uncertainties associated with each earthquake and the bias caused by different velocity models. For event location we used (i) the global AK135 model (Kenneth et al., 1995), (ii) the model that Geissler et al. (2010) used to locate local earthquakes to the SW of Portugal (Figure 4a, red line; called G-16); (iii) the velocity structure to the north of the Portimão Bank (Figure 4a, blue line; called OBS-Portimão) derived from 2-D seismic refraction data (Sallares et al., 2011), representing extended continental crust, and (iv) the velocity structure of the distal imbricated wedge derived from 2-D seismic refraction data (Sallares et al., 2011), representing Jurassic oceanic crust covered by $5 \mathrm{~km}$ of sediment (Figure 4a, green line; called OBS-prism).

In the individual location procedures, most earthquakes produced formal errors of $\pm 0.5-2 \mathrm{~km}$ for the epicentre and $\pm 2-5 \mathrm{~km}$ in focal depth. However, deeper earthquakes ( $>30 \mathrm{~km}$ ) may have larger epicentral errors of $\pm 2-4 \mathrm{~km}$ and $\pm 3-8 \mathrm{~km}$ in focal depth (Figure 4). Overall, seismic events with good azimuthal coverage provided very similar depth estimates, like two very well located thrust events at the Portimão Bank. The events occurred clearly within the upper mantle at 30-45 km (Figures 4 and 5). Depending on the velocity structure used for event location, event depth may vary by $\sim 10 \mathrm{~km}$ and epicentral locations may vary in the order of 2 to $20 \mathrm{~km}$. However, in a map view, changes of 
epicentres were generally minor. With respect to depth, changes are much more significant. The AK135 model provided the most compact depth distribution of all velocity models (Figure 6a) with basically all earthquakes occurring in the upper mantle. However, both crustal thickness and mantle velocity poorly match constraints from seismic data in the area. In fact AK135 includes a much thicker crust and faster mantle velocity than observed off SW Iberia (e.g., Sallares et al., 2011). The model G16 of Geissler et al (2010) approximates the onshore and offshore domains by using a crustal thickness of $16 \mathrm{~km}$, which is thinner than the crust of Iberia but thicker than the Jurassic oceanic crust sampled offshore (Sallares et al., 2011). In general, depth distribution of earthquakes is rather compact, ranging from $\sim 5 \mathrm{~km}$ to $\sim 45 \mathrm{~km}$ (Figure $6 \mathrm{~b}$ ). Thus, earthquakes occur both in the crust and upper mantle. The model OBS-Portimão has a crustal thickness of $28 \mathrm{~km}$ and a continental crust-type velocity structure. Depth distribution of earthquakes is similar to the model G-16, but showed a wider range in depth (Figure 6c). The model OBS-prism has approximately $5 \mathrm{~km}$ of sediments covering $7 \mathrm{~km}$ of oceanic crust. The depth distribution is scattered over a much larger depth range (Figure 6d). With respect to the average rms fit all four models provided in the NonLinLoc location procedure rather similar fits. Due to its compactness of depth distribution, we prefer the model G16. The fact that all models provide evidence for earthquakes rupturing at 30-50 km depth clearly supports the fact that a large number of earthquakes occurred within the mantle of the continental domain as defined by Martinez-Loriente et al. (2014; Figure 1).

The seismic velocity models constrained only the P-wave velocity structure. To constrain Vp/Vs ratios, we used Wadati diagrams (S-P time versus $\mathrm{P}$ time) and calculated an average $\mathrm{Vp} / \mathrm{Vs}$ ratio (Havskov and Ottemöller, 2000). To constrain the $\mathrm{Vp} / \mathrm{Vs}$ ratio we used 81 earthquakes with at least eight $\mathrm{P}$-wave and S-wave pairs, a rms event location misfit of 0.3 or better, and a correlation coefficient of the fit of $\mathrm{S}-\mathrm{P}$ time versus $\mathrm{P}$ time of $>0.9$. The resulting $\mathrm{Vp} / \mathrm{Vs}$ ratio was 1.68 .

To explore the benefit of having an amphibious network, we removed the OBS arrival times from the catalogue and re-located the events. For most offshore events the uncertainty increased and errors are doubled or even tripled. As an example Figure 5 shows the two thrust events of 5 and 18 of May of 2010. Removing the offshore stations, epicentres are shifted 5 to $10 \mathrm{~km}$ to the southwest and the probability-density-function (PDF) is smeared in SW-NE direction, indicating uncertainties of $\pm 5-8 \mathrm{~km}$. In depth, the PDF for the first event is not well defined (non Gaussian distribution) and uncertainties are in the order of $\pm 10-15 \mathrm{~km}$. For the second event, the preferred depth estimate would be at $20 \mathrm{~km}$ rather than at $38 \mathrm{~km}$. Like for the previous event, uncertainties are in the order $\pm 10-15 \mathrm{~km}$. Thus, offshore seismometers clearly improve the quality of event locations. Therefore, constraints from onshore networks alone might be profoundly biased. Supplementary Figure S1 shows the mislocation between regional catalogues and our estimates as a function of offset from the margin.

\subsection{Magnitudes}

Moment magnitudes were estimated for the CMG-40T sensors and onshore stations in Portugal using the method of Havskov and Ottemöller (2003). The two largest earthquakes recorded within the offshore network were a $\mathrm{Mw}=3.6$ thrust faulting earthquake in the vicinity of the Portimão Bank near OBS45 and a Mw=3.6 strike slip earthquake to the northwest of the Portimão Bank just west of OBS53. The largest earthquake that occurred during the deployment was a magnitude 4.3 event near the Moroccan coast about $180 \mathrm{~km}$ west of the city of Fez ( $\sim 30 \mathrm{~km}$ to the south west of seismic stations TSY), hitting on 22 April 2010. Most events, however, had magnitudes of $M w=2.2$ to 2.9. The smallest earthquakes had magnitudes of $\sim 1.8$. 


\subsection{Focal mechanisms}

In local marine earthquake studies, double-couple focal mechanisms are generally derived from first motion. Unfortunately, all recorded events were too small to allow regional moment tensor inversion using permanent networks. Thus, we derived fault plane solutions using HASH and FOCMEC algorithms (Hardebeck and Shearer, 2002; Snoke et al., 1984) and did not allow any polarity errors (Supplementary Figure S2). Here, we report only 6 mechanisms where both approaches provided similar solutions (Table 1).

\section{Results}

\subsection{Distribution of seismicity}

Seismicity in the Gulf of Cadiz and to the southwest of Portugal is not evenly distributed in space but highly clustered. During the deployment about half of the observed seismicity occurred to the west of the network, including areas of major activity at the Gorringe Bank, at the Sao Vicente Canyon to the south of the Cape Sao Vicente, and across the Horseshoe fault.

The area of largest activity well covered by the network occurred along the continental margin of southern Iberia to the north of $36^{\circ} \mathrm{N}$, including a number of $\mathrm{Mw}>3$ earthquakes at or in the vicinity of the Portimão Bank offshore Algarve (Figure 2). With a depth range of 15 to $\sim 40 \mathrm{~km}$, the majority of hypocentres occurred both within the lower crust and upper mantle. The two strongest and best located events occurred at $>30 \mathrm{~km}$ depth (independent of velocity model) and hence within the uppermost mantle (Figures 4 and 5). Figure 7 shows earthquakes to the east of $9^{\circ} 30^{\prime} \mathrm{W}$ (located with model G-16) projected on to the seismic refraction and wide-angle profile of Sallares et al. (2011). Interestingly, all earthquakes occurred below the $5-\mathrm{km} / \mathrm{s}$-contour line, suggesting that earthquakes occur within the basement and preferentially in the lower continental crust and uppermost mantle. Due to structural heterogeneities in the area and the fact that a 1-D reference model was used to locate the events, we carried out the same exercise using the other velocity models (Supplementary Figure 3 ). Overall, the features are very similar, supporting that the majority of earthquakes ruptured either in the lower crust or upper mantle. However, as indicated by the histograms in Figure 6 , the portion of earthquakes at mantle depth increases using either a thicker crust or global model.

On 22 of April 2010 the largest recorded event occurred roughly $100 \mathrm{~km}$ to the east of the marine network at the Moroccan coast line near the seismic station TSY. The earthquake with a magnitude of $m_{b}=4.5$ was recorded on nearly all stations of the network. The large spacing of seismic stations near the epicentre resulted in large uncertainties of focal depth. However, like the International Seismological Centre (ISC) (http://www.isc.ac.uk/iscbulletin/search/bulletin) we located the event within the mantle at $>40 \mathrm{~km}$.

An interesting feature is the almost lack of seismicity to the south of $36^{\circ} \mathrm{N}$ where sediment is thickest and the eastward dipping subduction thrust has been imaged (Guscher et al, 2002). Thus, basically all earthquakes occurred to the north of the 5 to $12 \mathrm{~km}$ thick accretionary prism (Figure 8a).

Furthermore, in the same area major strike slip faults (Zitellini et al., 2009; Bartolome et al., 2012) have been deduced from bathymetric and seismic data (labelled SWIM1 and SWIM2 in Figure 1 and 2). However, over the six month of network operation little evidence for seismogenic slip along the faults was observed. Just to the west of OBS39 and OBS41, some seismicity might be associated with the SWIM1 fault. Trade-offs between epicentral location and focal depth cause too large uncertainties to draw any robust conclusions regarding these particular events. 
Most earthquakes along the margin might be related to the structure of the margin. Gràcia et al. (2003) highlighted a prominent SW-NE striking gravity anomaly - the Guadalquivir-Portimao lineament - terminating at the Portimão Bank. Most earthquakes at the margin seem to occur in the vicinity of this anomaly (Figure $8 \mathrm{~b}$ ), suggesting that the structure of the margin controls the distribution of seismicity. Plotting data obtained from regional catalogues, like the IPMA or IGN seismic bulletins, provide basically the same pattern (Fig. 8c and 8d).

\subsection{Stress pattern}

Focal mechanisms were derived for six earthquakes. In the vicinity of the Portimão Bank thrusting dominates (Figures 2). However, the same stress pattern may be compatible with two sets of conjugate faults, both accommodating general N-S trending shortening. To the northwest of the Portimão Bank two strike-slip events were deduced (Figure 2). Overall, focal mechanisms and hence stress pattern mimic features observed in previous studies (e.g., Borges et al., 2001; Stich et al., 2005).

\section{Discussion}

\subsection{Seismicity to the southwest of Portugal}

The seismicity reported routinely by the Portuguese IPMA or the Spanish IGN shows clustered seismicity at Gorringe Bank and at the Sao Vicente Canyon, indicating different active fault systems (e.g., Geissler et al., 2010). All areas showed seismic activity during the 6 month of network operation. Unfortunately, events recorded at both the Gorringe Bank and at the Horseshoe Fault where well outside of the network and hence hypocentral parameters have too large uncertainties. Trade-offs between focal depth and epicentral distance prevent robust estimates of either focal depth or stress pattern. However, due to its proximity to seismic stations in Portugal and the marine network, seismicity at the Sao Vicente Canyon can be studied in much more detail. Over the deployment period we recorded more than 20 earthquakes that clustered near the southwestern terminus of the canyon, making it one of the seismically most active sites. Focal depth of 20 to $40 \mathrm{~km}$ indicates that seismicity is generally located within the mantle. Geissler et al. (2010) located earthquakes in the vicinity of the Sao Vicente fault at a greater depth of 40 to $55 \mathrm{~km}$. Focal mechanism and stress tensor inversion of Geissler et al. (2010) yielded an obliquely oriented compressive regime. The single focal mechanisms obtained during our deployment supports the stress pattern observed previously.

\subsection{Seismicity of the southern Iberia continental margin}

The northern Gulf of Cadiz has been divided into an inner part (off the city of Cadiz), a middle part with the Guadalquivir Bank, and an outer part with the Portimão Bank (Gràcia et al., 2003). The outer part is characterized by a rough topography and is dominated by large submarine canyons that are deeply incised in platformal areas. To the south, both the Portimão Bank and Guadalquivir Bank show thrust faults (Gràcia et al., 2003). During the marine deployment, the middle and outer part of the Gulf of Cadiz were seismically very active. Three thrust faulting events occurred at the Portimão Bank and focal depth of the thrust events clearly support that they rupture within the mantle 
(Figures 4, 5 and 7). Based on bathymetric and seismic data, it has been suggested that the Bank is bounded at both flanks by thrust faults (Gràcia et al., 2003; Terrinha et al., 2009). Sallares et al. (2011) found southward dipping seismic velocity anomalies that were interpreted as crustal scale normal faults formed during the formation of the passive margin in the Mesozoic. It might be reasonable to suggest that these faults cut into the mantle and are reactivated in response to the convergence between Africa and Eurasia as thrusts.

For the US east coast stress pattern indicated roughly margin parallel compression (Zoback, 1992), which is similar to stresses caused by modelled intraplate stresses due to plate-wide forces. Earthquakes along the eastern continental margin of the US are generally believed to reflect reactivation of ancient faults (Wolin et al., 2012). Along the Iberian margin, Zitellini et al. (2004) suggested that seismic activity occurs along reactivated Mesozoic rift structures. Thus, earthquakes along the south Iberian continental margin mimic stresses and features envisioned for the US east coast. The increased seismicity rate for the Iberian margin, however, may reflect its proximity to the African/Eurasian plate boundary.

The main difference, however, is the much larger focal depth of most earthquakes reported in our study. Typical earthquakes along passive continental margins, like the 23rd August 2011 Mineral, Virginia event (Wolin et al., 2012) or the 23rd April 2008 Sao Vicente, Brazil event (Assumpcao et al., 2011), occurred within the crust. In contrast, earthquakes along the southern Iberia margin occurred predominately within the mantle. We hypothesize that this feature is caused by the proximity to the plate boundary and by an elastic rheology of the continent-ocean transition zone (see discussion below).

Overall, our new depth estimates support previous results obtained from global catalogues and regional waveform modelling (Stich et al., 2005), showing seismicity both in the crust and upper mantle. However, events as deep as $60 \mathrm{~km}$, that were previously reported (Stich et al., 2005), have not been observed during our deployment. The stress pattern derived from the amphibious network support features obtained previously (e.g., Borges et al., 2001; Stich et al., 2005), suggesting that the Southern Iberian margin is under horizontal compression. However, there is not a dominant faulting regime, hence reverse, strike-slip, and normal faulting mechanisms coexist in the Gulf of Cadiz and SW Iberia (e.g., Borges et al., 2001; Buforn et al., 2004; Stich et al., 2005; Geissler et al., 2010). Terrinha et al. (2009) suggested that such pattern might be related to convergence and strain partitioning by means of dextral wrenching on WNW-ESE trending steep faults and thrusting on the NE-SW trending fault in the Gulf of Cadiz and Horseshoe Abyssal Plain. Approaching the base of the continental slope, NNE-SSW to N-S westerly dipping thrusts accommodate shortening in an area where wrenching has not been observed.

\subsection{Rheology of crust and mantle}

In continental lithosphere it has been observed that during rifting the upper crust is deformed by faulting while the lower crust generally supports ductile deformation (e.g., Odedra et al., 2001; Moeller et al., 2013). The transition from brittle to ductile deformation depends on the temperature structure and the rock type. Earthquakes are generally restricted to domains of brittle deformation. The fact that earthquakes in the Gulf of Cadiz occur within the lower crust and the upper mantle supports elastic rheology for both domains. Thus, both the lower crust and upper mantle are strong. This interpretation is supported by very low crustal heat flow of $<50 \mathrm{~mW} / \mathrm{m}^{2}$ (Grevemeyer et al., 
2009), resulting in cooler geotherms than generally found in rift basins (e.g., McKenzie, 1978) and hence favouring elastic rheology.

Brittle deformation in the oceanic mantle is a common features and generally restricted to temperatures $<600^{\circ} \mathrm{C}$ (e.g., McKenzie et al., 2005; Craig et al., 2014). Thus, only near mid-ocean ridges is seismicity confined to crustal levels (e.g., Grevemeyer et al., 2013). Crustal deformation of mature oceanic lithosphere may cause brittle deformation to extend until depths of several tens of kilometres into the mantle (Lefeldt et al., 2009; Craig et al., 2014). In our study the majority of earthquakes rupturing within the mantle occurred landward of the domain of Jurassic oceanic crust, either in the 60-km-wide continent-ocean transition zone or in the continental domain near the coast line as defined by seismic data (Sallares et al., 2011; Martinez-Loriente et al., 2014; Figure 1).

Earthquakes in the continental domain of the South Iberia margin are focused in the lower crust and uppermost mantle. Neves and Neves (2009) suggested that flexural loading caused by density contrasts between adjacent oceanic and continental crust may cause flexure and hence deformation. In their model compressive stresses and deformation concentrates below Moho. However, some of the best located earthquakes occur in the continent-ocean transitions zone (line-km 160 to 190 in Figure 5) at $\sim 40 \mathrm{~km}$ depth where the flexural model of Neves and Neves (2009) predicts tensile stresses. In contrast, observed focal mechanisms support thrusting and hence compression.

Seismicity and brittle deformation in both oceanic and continental mantle off southern Iberia seems to be a common feature and have been revealed using a wide range of techniques, including regional waveform modelling (Stich et al., 2005) and local monitoring of seismicity using our amphibious network. Elsewhere in continental lithosphere earthquakes occurring at mantle depth are known to be rare. It was therefore inferred that the continental mantle is rather weak and probably related to higher water content (Maggi et al., 2000). Mantle earthquakes, however, were detected beneath the East African Rift at 53 to $60 \mathrm{~km}$ (Lindenfeld and Rümpker, 2011), but might be associated to deepseated magmatic processes. Recently, Alinaghi and Krüger (2014) confirmed the occurrence of some earthquakes in continental mantle below the Tien Shan, Central Asia, supporting a strong lower crust and upper mantle.

\subsection{Seismic quiescence of the Gulf of Cadiz sedimentary prism and SWIM faults}

A large number of ocean-bottom-seismometers was placed on the accretionary prism of the Gulf of Cadiz (Figure 2; Gutscher et al., 2002; Thiebot and Gutscher, 2006). Seismically the area remained inactive, both during the time of our deployment and during the much longer time scale of seismicity recorded by national networks in Portugal and Spain (Figure 8). Seven OBS (no 37 to 43) where located on top of the main SWIM fault running through the centre of the Gulf (labelled SWIM1 in Figures 1 and 2). These stations were deployed as a dense array with a station separation of $<10 \mathrm{~km}$. Nevertheless, they did not reveal any earthquakes within the network that cluster along the fault. However, some events farther west but outside of the network might be associated with the SWIM1 fault. One interpretation would be that both the subduction thrust and the SWIM faults are largely inactive. However, large strike-slip faults might be segmented, like the San Andreas Fault in California (e.g., Bennett et al., 2004). Consequently, the segment of the SWIM fault covered by the network might be either inactive, creeping or being lock, while farther west, where a number of earthquakes cluster in the vicinity of the fault, earthquakes may indicate activity.

The idea of active subduction in the Gulf of Cadiz is still under debate. Plate tectonic reconstructions of the Western Mediterranean suggests that the Oligocene/Miocene evolution was driven by 
subduction and slab roll-back (e.g., Faccenna et al., 2001). A remaining slab of eastward subduction has been imaged under the western Alboran Sea (e.g., Garcia-Castellanos and Villaseñor, 2011; Bezada et al., 2013) and geochemical studies of magmatic rocks from the Alboran Sea suggest that subduction related volcanism occurred until Miocene times (Duggen et al., 2003, 2004). The existence of a Miocene magmatic arc in the Alboran Sea has been supported by seismic reflection imaging (Booth-Rea et al., 2007). However, arc magmatism in the Alboran Sea stopped in the Miocene (Duggen et al., 2003, 2004) and the stratigraphic analysis of seismic data from the Gulf of Cadiz may support the interpretation that accretion has stopped several million years ago (Iribarren et al., 2007). This conclusion is sustained by simulating the tectonic reconstruction of the western Mediterranean using 3-D numerical modelling, indicating that subduction roll-back is stalled since Tortonian ( 8 Ma) (Chertova et al., 2014). In terms of these results it seems reasonable to suggest that subduction has largely ceased and hence the former megathrust might be seismically inactive. However, a lack of seismicity itself cannot be used to argue that subduction ceased. For example, a number of subduction megathrusts remain seismically inactive, like the Cascadia subduction zone offshore of Oregon and British Columbia. Tsunami deposit found in the trench of Cascadia and even thousands of kilometres away in Japan suggest that Cascadia suffers from a major magnitude $\mathrm{M} \sim 9$ earthquake every 300 to 800 years (Satake et al.; 1996; 2003). Thus, depending on convergence rate, such settings may support catastrophic earthquakes with large recurrence intervals of several hundreds to thousands of years. Consequently, the observed quiescence to the south of $36^{\circ} \mathrm{N}$ cannot be used to rule out a future megathrust earthquake.

Zitellini et al. (2009) presented the SWIM faults as being a developing plate boundary. The fact that the plate boundary is yet not fully developed has been indicated by current stress indicators, like GPS velocities and earthquake rates (Cunha et al., 2012). However, an alternative interpretation might be that the SWIM faults comprise several smaller fault segments rather than acting like a single $600 \mathrm{~km}$ long faults zone. The fact that some segments of the SWIM faults are actively slipping is supported by seismic reflection imaging (Bartolome et al., 2012) and probably by a number of not so well located earthquakes to the west of the network. In addition, Geissler et al. (2010) reported a single strike-slip mechanism in the vicinity of the SWIM1 fault. Thus, the observed seismicity pattern and the lack of seismicity along major parts of the fault could also be interpreted as being related to a segmented fault and the seismic cycle. Today, we know that earthquakes are the result of a stick-slip frictional instability (Brace and Byerlee, 1966), where "the earthquake is the 'slip' and the 'stick' is the interseismic period of elastic strain accumulation" (Scholz, 1998). Within the cycle, the interseismic stain accumulation might be aseismic. Such features were observed along the most prominent fault in the Gulf of Almeria - the $100 \mathrm{~km}$ long northeast-southwest trending left-lateral strike-slip Carboneras Fault (Gràcia et al., 2006). The fault remained seismically inactive during a 5 months long seismic monitoring campaign (Grevemeyer et al., 2015). However, the Carboneras Fault is associated with a number of historic earthquakes, affecting the city of Almeria in southern Spain. Furthermore, geomorphic features found along the strike-slip fault clearly indicated active motion (Gràcia et al., 2006). In terms of the evidence found at the Carboneras Fault, we suggest that the SWIM faults mimic the Carboneras Fault. Thus, they might be either creeping or accumulating strain being released in future seismic activity.

\subsection{A passive-aggressive margin or an active plate boundary?}

The features discussed above clearly indicate that seismicity along the southern Iberia margin resembles activity found along the passive continental margins of the eastern US (Zoback, 1992; Wolin et al., 2012) and Brazil (Assumpcao et al., 2011); the main differences being that earthquakes 
tend to occur at crustal levels along the American passive margins, while most events in the Gulf of Cadiz rupture at mantle depth. Moreover, the rate of seismicity off Iberia is much higher.

An active plate boundary or STEP fault (Govers and Wortel, 2005) running from the Betics into the Gulf of Cadiz would favour a rather continuous band of seismicity. However, it is observed that seismicity and deformation is spread over a wider area rather than representing a discrete fault (e.g., Sartori et al., 1994; Hayward et al., 1999), supporting a rather diffusive plate boundary. Alternatively, Terrinha et al. (2009) advocated a regional (large scale) strain partitioning scenario, suggesting that the WNW-ESE convergence between both plates is simultaneously accommodated by (i) right-lateral strike-slip movement (along the SWIM fault system) and (ii) thrusting along NNE-SSW to N-S directed faults. Either, a rather diffusive plate boundary or strain partitioning may explain the much higher rate of seismicity off Iberia when compared to other passive margins. Besides, passive margins are generally several thousands of kilometres from any plate boundary and hence in the plate interior. In contrast, the south Iberian margin is situated about $100-200 \mathrm{~km}$ off Africa. Thus, normal passive margins suffer from far field stresses, while southern Iberia suffers from regional stresses caused by collision.

The fact that mantle earthquakes dominate in the Gulf of Cadiz might be caused by deformation associated with a rather unique setting. First, the Triassic to Jurassic age of the margin makes Iberia one of the oldest passive margins. Second, collision is generally not associated with active subduction. Third, in the center of the Gulf of Cadiz a fragment of Jurassic oceanic lithosphere (Figure 1; Sallares et al., 2011; Martinez-Loriente et al., 2014) is sandwiched between African and Eurasian continental lithosphere. Thus, convergence between both continents will push thick Jurassic oceanic lithosphere against Triassic continental lithosphere. Shortening and deformation of such old and hence rigid lithosphere may cause intense deformation at mantle depth, explaining the large number of mantle earthquakes.

If the margin parallel seismicity would be related to an active STEP fault (Govers and Wortel, 2005) and westward slab retreat (e.g. Gutscher, 2004; Gutscher et al., 2012), we would expect a rather continuous band of seismicity outlining a major active fault. However, neither the Portuguese nor the Spanish national catalogues indicate such features, but show two unrelated clusters of activity at the Algarve margin and in the Betics (Figure 8). An inactive STEP fault would be supported by stalled subduction and slab retreat (Chertova et al., 2014). Off the Algarve coast to the west of $7^{\circ} \mathrm{W}$, earthquakes are co-located with a prominent gravity anomaly, supporting that seismicity is related to pre-existing features of the passive margin that are re-activated by the convergence between Africa and Eurasia (Zitellini et al., 2004). A new plate boundary fault may develop further south (Zitellini et al., 2009) along the SWIM faults. We therefore suggest classifying the margin of southern Iberia as a rather active and hence seismically aggressive-passive margin.

\section{Conclusions}

An amphibious micro-seismicity survey was conducted in the northern Gulf of Cadiz and Algarve passive margin, indicating that

(i) the majority of earthquakes was either located in the lower crust or the upper mantle. Roughly $50 \%$ of the detected events occurred either in the oceanic mantle of Jurassic lithosphere or beneath the continent-ocean transition zone and continental crust of the south Algarve-Iberia margin.

(ii) Seismicity pattern supports a strong lower crust and upper continental mantle. 
(iii) We consider the margin as a rather active or "aggressive" passive margin where preexisting faults are re-activated by the African/Eurasian plate convergence. This conclusion is supported by the fact that seismicity found along the Algarve margin mimics the fault pattern along the passive margin of the Eastern US (Zoback, 1992; Wolin et al., 2012) and Eastern Brazil (Assumpcao et al., 2011).

(iv) Little evidence was found that the SWIM faults, as lithospheric scale W-E trending strikeslip faults, were seismically active during the offshore deployment.

(v) We did not observe any earthquakes supporting an active eastward dipping subduction zone.

\section{Acknowledgements}

This study is part of the TOPO-EUROPE initiative of the EUROCORES Programme of the European Science Foundation (ESF). The German efforts of TOPO-MED were funded by the German Science Foundation (DFG grant GR1964/12-1) and COST Action ES1301 "FLOWS". We thank the "German Instrument Pool for Amphibian Seismology (DEPAS)", hosted by the Alfred Wegener Institute Bremerhaven, providing five OBS operating CMG-40T sensors. We like to thanks Captain Michael Schneider and his crew of R/V Poseidon cruise POS393 and Captain Friedhelm von Star and the crew of R/V Maria S. Merian cruise MSM15/5 for excellent sea-going support. We are thankful to Anke Dannowski, Wiebke Leuchters, Helene Kraft, Arne Schwenk, Erick Labahn and students for technical assistance in operating ocean-bottom-seismometers. We greatly appreciate the detailed reviews of two anonymous referees that greatly improved the discussion of implications introduced by our new data. Figures were produced using the Generic Mapping Tools (GMT) software (Wessel and Smith, 1998). This work included data from the PM and WM seismic networks obtained from the GEOFON data centre.

\section{References}

Alinaghi, A., Krüger, F., 2014. Seismic array analysis and redetermination of depth of earthquakes in Tien-Shan: implications for strength of the crust and lithosphere. Geophys. J. Int. 198, 11111129, doi:10.1093/gji/guu141.

Assumpcao, M., Dourado, J.C., Ribotta, L.C., Mohriak, W.U., Dias, F.L., and Barbosa, J.R., 2011, The Sao Vicente earthquake of 2008 April and seismicity in the continental shelf off SE Brazil: further evidence for flexural stresses Geophys. J. Int., 187, 1076-1088, doi: 10.1111/j.1365246X.2011.05198.x

Bartolome, R., Gràcia, E., Stich, D., Martinez-Loriente, S., Klaeschen, D., Mancilla, F., lacono, C., Danobeitia, J.J., Zitellini, N., 2012. Evidence for active strike-slip faulting along the Eurasia-Africa convergence zone: implications for seismic hazard in the southwest Iberia margin. Geology 40, 495-498, doi:10.1130/G33107.1

Baptista, M.A., Miranda, P.M.A., Miranda, J.M., Victor L.M., 1998. Constrains on the source of the 1755 Lisbon tsunami inferred from numerical modelling of historical data. Journal of Geodynamics 25, 159-174.

Baptista, M.A., Miranda, J.M., Omira, R., Antunes, C., 2011. Potential inundation of Lisbon downtown by a 1755-like tsunami, Nat. Hazards Earth Syst. Sci., 11, 3319-3326. 
Bennett, R.A., Friedrich, A.M., Furlong, K.P. 2004. Codependent histories of the San Andreas and San Jacinto fault zones from inversion of fault displacement rates. Geology 2004; 32; 961-964. doi: 10.1130/G20806.1

Bent, A. L., 1995. A complex double-couple source mechanism for the Ms 7.2 1929 Grand Banks earthquake. Bull. Seismol. Soc. Am., 85, 1003-1020.

Bezada, M.J., Humphreys, E.D., Toomey, D.R., Harnafi, M., Davila, J.M., 2013. Evidence for slab rollback in westernmost Mediterranean from improved upper mantle imaging. Earth Planet. Sci. Lett. 368, 51-60.

Booth-Rea., G., Ranero, C.R., Martinez-Martinez, J.M., and Grevemeyer, I., 2007, Crustal types and Tertiary tectonic evolution of the Alboran Sea, western Mediterranean, Geochem. Geophys. Geosyst., 8, doi:10.1029/2007GC001639.

Borges, J.F., Fitas, A.J.S., Bezzeghoud, M., Teves-Costa, P., 2001. Seismotectonics of Portugal and its adjacent Atlantic area. Tectonophysics 337, 373-387.

Brace, W.F., and Byerlee, J.D., Stick-slip as a mechanism for earthquakes, Science, 153, 1966, 990.

Buforn, E., Bezzeghoud, M., Udías, A., Pro, C., 2004. Seismic Sources on the Iberia-African Plate Boundary and their Tectonic Implications. Pure App. Geophys. 161, 623-646.

Chertova, M. V., Spakman, W., van den Berg, A.P., van Hinsbergen, D.J.J., 2014. Absolute plate motions and regional subduction evolution, Geochem. Geophys. Geosyst., 15, doi:10.1002/2014GC005494.

Cloetingh, S., Beekman, F., Ziegler, P., van Wees, J., Sokoutis, D., 2008. Post-rift compressional reactivation potential of passive margins and extensional basins, in Nature and Origin of Compression in Passive Margins. Geol. Soc. Spec. Publ. 306, 27-70, doi:10.1144/SP306.2.

Craig, T.J., Copley, A., Jackson, J., 2014. A reassessment of outer-rise seismicity and its implications for the mechanics of oceanic lithosphere. Geophys. J. Int. 197, 63-89, doi:10.1093/gji/ggu013.

Cunha, T.A., Matias, L.M., Terrinha, P., Negredo, A., Rosas, F., Fernandes, R.M.S., Pinheiro, L.M., 2012, Neotectonics of the SW Iberia margin, Gulf of Cadiz and Alboran Sea: a reassessment including recent structural, seismic and geodetic data. Geophys. J. Int. 188, 850-872.

DeMets, C.,Gordon, R.G., Argus, D.F., 2010, Geologically current plate motions, Geophys. J.Int.181,180.

Díaz, J., Gallart, J., 2014. Seismic anisotropy from the Variscan core of Iberia to the Western African Craton: New constrains on upper mantle flow at regional scales, Earth Planetary Sci. Lett., 394, Doi: 10.1016/j.epsl.2014.03.005.

Duarte, J.C., Rosas, F.M., Terrinha, P., Gutscher, M.-A., Malavieille, J., Silva, S., Matias, L., 2011. Thrust-wrench interference tectonics in the Gulf of Cadiz (Africa-lberia plate boundary in the north-east Atlantic): insights from analog models. Marine Geology 289, 135-149.

Duggen, S., Hoernle, K., van den Bogaard, Rüpke, L., Phipps Morgan, J., Deep roots of the Messinian salinity crisis, Nature, 422, 2003, 359-363.

Duggen, S., Hoernle, K., van den Bogaard, P., and Harris, C., The role of subduction in forming the western Mediterranean and causing the Messinian salinity crisis, Earth. Planet. Sci., Lett., 218, 2004, 91-108.

Faccenna, C., Becker, T.W., Pio-Lucente, F., Jolivet, L., Rosseti, F., 2001. History of subduction and backarc extension in the Central Mediterranean, Geophys. J. Int., 145, 809-820.

Fukao, Y., Thrust faulting at a lithospheric plate boundary, the Portugal earthquake of 1969, Earth Planet. Sci. Lett., 18, 1973, 205-216.

Garcia-Castellanos,D., Villaseñor, A., 2011. Messinian salinity crisis regulated by competing tectonics and erosion at the Gibraltar arc. Nature 480, 359-363.

Geissler, W.H. et al., 2010. Focal mechanisms for sub-crustal earthquakes in the Gulf of Cadiz from a dense OBS deployment. Geophys. Res. Lett. 37, L18309, doi:10.1029/2010GL044289. 
Govers, R.,Wortel, M.J.R., 2005. Lithosphere tearing at STEP faults: Response to edges of subduction zones, Earth and Planetary Science Letters 236 (2005) 505- 523.

Gràcia, E., Danobeitia, J.J., Verges, J., Bartolome, R., 2003. Crustal architecture and tectonic evolution of the Gulf of Cadiz (SW Iberian margin) at the convergence of the Eurasian and African plates. Tectonics 22, 1033, doi:10.1029/2001TC901045.

Gràcia, E., Pallàs, R., Soto, J.I., Comas, M., Moreno, X., Masana, E., Santanach, P., Diez, S., García,M., Dañobeitia, J.J., 2006. Active faulting offshore SE Spain (Alboran Sea): implications for earthquake hazard assessment in the Southern Iberia Margin. Earth Planet. Sci. Lett. 241, 734749.

Grandin, R., Borges, J.F., Bezzeghoud, M., Caldeira, B., Carrilho, F., 2007. Simulations of strong ground motion in SW Iberia for the 1969 February 20 (Ms=8.0) and the 1755 November 1 (M 8.5) earthquakes - II. Strong ground motion simulations. Geophys. J. Int. 171, 807-822.

Grevemeyer, I., Kaul, N., Kopf, A., 2009. Heat flow anomalies in the Gulf of Cadiz and off Cape San Vincente, Portugal. Mar. Petrol. Geol. 26, 795-804, doi:10.1016/j.marpetgeo.2008.08.006.

Grevemeyer, I., Reston, T.J., Moeller, S., 2013. Microseismicity of the Mid-Atlantic Ridge at $7^{\circ} \mathrm{S}-8^{\circ} 15^{\prime} \mathrm{S}$ and at the Logatchev Massif oceanic core complex at $14^{\circ} 40^{\prime} \mathrm{N}-14^{\circ} 50^{\prime} \mathrm{N}$. Geochem. Geophys. Geosyst. 14, 3532-3554, doi:10.1002/ggge.20179.

Grevemeyer, I., Gràcia, E., Villaseñor, A., Leuchters, W., Watts, A.B., 2015. Seismicity and active tectonics in the Alboran Sea, Western Mediterranean: Constraints from an offshore-onshore seismological network and swath bathymetry data, J. Geophys. Res. 120, doi:10.1002/2015JB012073.

Gutscher, M.-A., Malod, J., Rehault, J.-P., Contrucci, I., Klingelhoefer, F., Mendes-Victor, L., Sparkman, W., 2002. Evidence for active subduction beneath Gibraltar. Geology 30, 1071-1074.

Gutscher, M.A., Baptista, M.A., Miranda, J.M., 2006. The Gibraltar Arc seismogenic zone: Part 2. Constraints on a shallow east dipping fault plane source for the 1755 Lisbon earthquake provided by tsunami modeling and seismic intensity. Tectonophysics 426, 153-166.

Gutscher, M.A., et al., 2012, The Gibraltar subduction: A decade of new geophysical data, Tectonophysics, 574-575, 72-91, doi:10.1016/j.tecto.2012.08.038

Gutscher,M.A., 2004. What Caused the Great Lisbon Earthquake? Perspectives, Science 305, 12471248.

Hardebeck, J. L., Shearer, P.M., 2002. A new method for determining first-motion focal mechanisms. Bull. Seismol. Soc. Am. 92, 2264-2276, doi:10.1785/0120010200.

Havskov, J., Ottemöller, L., 2000. SEISAN earthquake analysis software. Seismol. Res. Lett. 70, 532534.

Heymann, M.A.W., 1989. Tectonic and depositional history of the Moroccan continental margin. In: Tankard, A.J., Balkwill, H.R. (Eds.), Extensional Tectonics and Stratigraphy of the Northern Atlantic Margins. Am. Assoc. Pet. Geol. and Can. Geol. Found. AAPG Mem. 46, 323-340.

Hayward, N., Watts, A.B., Westbrook, G.K., and Collier, J.S., 1999, A seismic reflection and GLORIA study of compressional deformation in the Gorringe Bank region, eastern north Atlantic, Geophy. J., Int., 138, 831-850.

Iribarren, L., Verges J., Camurri, F., Fullea, J., Fernandez, M., 2007. The structure of the AtlanticMediterranean transition zone from the Alboran Sea to the Horseshoe Abyssal Plain (IberiaAfrica plate boundary). Mar. Geol. 243, 97-119.

Johnston, A., 1996. Seismic moment assessment of earthquakes in stable continental regions - III. New Madrid, 1811-1812, Charleston 1886 and Lisbon 1755. Geophys. J. Int. 126, 314-344.

Kennett, B. L. N., Engdahl, E. R., Buland, R., 1995. Constraints on seismic velocities in the Earth from traveltimes. Geophys. J. Int. 122, 108-124, doi:10.1111/j.1365-246X.1995.tb03540.x. 
Lefeldt, M., Grevemeyer, I., Gossler, J., Bialas, J., 2009., Intraplate seismicity and related mantle hydration at the Nicaraguan trench outer rise, Geophys. J. Int. 178,742-752, doi:10.1111/j.1365246X.2009.04167.x.

Lienert, B.R., Berg, E., Frazer, L.N., 1986. Hypocenter: an earthquake location method using centered, scaled, and adaptively least squares. Bull. Seismol. Soc. Am. 76, 771-783.

Lienert, B.R., Havskov, J., 1995. Hypocenter 3.2: A computer program for locating earthquakes locally, regionally and globally. Seismol. Res. Lett. 66, 26-36.

Lindenfeld, M., Rümpker, G., 2011. Detection of mantle earthquakes beneath the East African Rift, Geophys. J. Int. (2011) 186, 1-5, doi: 10.1111/j.1365-246X.2011.05048.x

Lomax, A., Virieux, A. J., Volant, P., Berge, C., 2000. Probabilistic earthquake location in 3D and layered models: Introduction of a Metropolis-Gibbs method and comparison with linear locations, in Advances in Seismic Event Location, pp. 101-134, eds. Thurber, C. H. and Rabinowitz, N., Kluwer, Amsterdam.

Maggi, A., Jackson, J.A., McKenzie, D., Priestley, K., 2000. Earthquake focal depth, effective elastic thickness, and the strength of the continental lithosphere. Geology 28, 495-498.

Maldonado, A., Somoza, L., Pallare、 s, L., 1999. The Betic orogen and the Iberian-African boundary in the Gulf of Cadiz: geological evolution (Central North Atlantic). Mar. Geol. 155, 9-43.

Martinez-Solares, J.M., Lopez, A., Mezcua, J., 1979. Isoseismal map of the 1755 Lisbon earthquake obtained from Spanish data. Tectonophysics 53, 301-313.

Martinez-Loriente, S. et al., 2014. Seismic and gravity constraints on the nature of the basement in the Africa-Eurasia plate boundary: New insights for the geodynamic evolution of the SW Iberian margin. J. Geophysical Research 119, 127-149, doi: 10.1002/2013JB010476

McKenzie, D.; Parker, R.L., 1967. The North Pacific: an example of tectonics on a sphere. Nature 216 1276-1280, doi:10.1038/2161276a0.

McKenzie, D., 1978. Some remarks on the development of sedimentary basins. Earth Plant. Sci. Lett. 40, 25-32.

McKenzie, D., Jackson, J.A., Priestley, K., 2005. Thermal structure of oceanic and continental lithosphere. Earth. Planet. Sci., Lett. 233, 337-349, doi:10.1016/j.eps/2005.02.005.

Moeller, S., Grevemeyer, I., Ranero, C.R., Berndt, C., Klaeschen, D., Sallares, V., Zitellini, N., de Franco, R., 2013. Early-stage rifting of the northern Tyrrhenian Sea Basin: Results from a combined wideangle and multichannel seismic study. Geochem. Geophys. Geosyst., 14, 3032-3052, doi:10.1002/ggge.20180.

Morgan, W. J., 1968. Rises, Trenches, Great Faults, and Crustal Blocks. J. Geophys. Res. 73, 19591982, doi:10.1029/JB073i006p01959.

Neves, M.C., Neves, R.G.M., 2009. Flexure and seismicity across the ocean-continent transition in the Gulf of Cadiz. J. Geodynamics, 47, 119-129.

Odedra, A., Ohnaka, M., Mochizuki, H., Sammonds, P., 2001. Temperature and pore pressure effects on the shear of strength of granite in the Brittle-Plastic Transition Regime. Geophys. Res. Lett. 28, 3011-3014, doi:10.1029/2001GL013321.

Ottemöller, L., Havskov, J., 2003. Moment magnitude determination for local and regional earthquakes based on source spectra. Bul. Seism. Soc. Am. 93, 203-214

Rovere, M., Ranero, C.R., Sartori, R., Torelli, L., Zitellini, N., 2004. Seismic images and magnetic signature of Late Jurassic to Early Cretaceous Africa-Eurasia plate boundary off SW Iberia. Geophys. J. Int. 158, 554-568.

Royden, L. H. (1993). Evolution of retreating subduction boundaries formed during continental collision, Tectonics, 12, 629-638.

Sandwell, D.T., Müller, R.D., Smith, W.H.F., Garcia, E., Francis, R., 2014. New global marine gravity model from CryoSat-2 and Jason-1 reveals buried tectonic structure. Science 346, 65-67, doi:10.1126/science. 1258213 
Sallares, V. et al., 2011., Seismic evidence for the presence of Jurassic oceanic crust in the central Gulf of Cadiz (SW Iberia margin). Earth Plant. Sci. Lett. 311, 112-123, doi.10.1016/j.epsl.2011.09.003.

Satake, K., Shimazaki, Tsuji, K., Ueda, K., 1996. Time and size of a giant earthquake in Cascadia inferred from Japanese tsunami record of January 1700, Nature, 379, 246-249.

Satake, K., Wang, K., Atwater, B.F., 2003. Fault slip and seismic moment of the 1700 Cascadia earthquake inferred from Japanese tsunami description, J. Gephys. Res., 108, 2325, doi:10.1019/2003JB002521.

Scholtz, C.H, 1998, Earthquakes and friction laws, Nature, 391, 38-42.

Spakman, W., Wortel, R., 2004. A tomographic view on Western Mediterranean Geodynamics, in The TRANSMED Atlas, The Mediterranean Region from Crust to Mantle, eds Cavazza, W., Roure, F., Spakman, W., Stampfli, G.M., Ziegler, P., pp 31-52.

Sartori, R., Torelli, L., Zitellini, N., Peis, D., and Lodolo, E., 1994. Eastern segment of the AzoresGibraltar line (central-eastern Atlantic): an oceanic plate boundary with diffuse compressional deformation. Geology 22, 555-558.

Schettino, A., Turco, E., 2011. Tectonic history of the western Tethys since the Late Triassic. Geol. Soc. Am. Bull. 123, 89-105, doi:10.1130/B30064.1.

Schulte, S. M., Mooney, W.D., 2005. An updated global earthquake catalogue for stable continental regions. Geophys. J. Int. 161, 707-721, doi:10.1111/j.1365-246X.2005.02554.x.

Snoke, J.A., Munsey, J.W., Teague, A.G., Bollinger, G.A., 1984. A program for focal mechanism determination by combined use of polarity and SV-P amplitude ratio data. Earthquake notes 55.

Stich,D., de Lis Mancilla, F., Morales, J., 2005. Crust-mantle coupling in the Gulf of Cadiz (SW-Iberia), Geophys. Res. Lett., 32, doi:10.1029/2005GL023098.

Terrinha, P., et al., 2009. Morphotectonics and strain partitioning at the Iberia-Africa plate boundary from multibeam and seismic reflection data. Marine Geology, 267, 156-174, doi:10.1016/j.margeo.2009.09.012.

Thiebot, E., Gutscher, M.A., 2006. The Gibraltar Arc seismogenic zone (part1): constraints on a shallow east dipping fault plane source for the 1755 Lisbon earthquake provided by seismic data, gravity and thermal modeling. Tectonophysics 427, 135-152.

Torelli, L., Sartori, R., Zitellini, N., 1997. The giant chaotic body in the Atlantic ocean of Gibraltar. New result from a deep seismic reflection survey. Mar. Petrol. Geol. 14, 125-138.

Wessel, P., Smith, W.H.F., 1998. New improved version of the Generic Mapping Tool Released, EOS Trans. Am. geophys. Un., 79, 579.

Wolin, E., Stein, S., Pazzaglia, F., Meltzer, A., Kafka, A., Berti, C., 2012. Mineral, Virginia, earthquake illustrates seismicity of a passive-aggressive margin. Geophys. Res. Lett. 39, L02305, doi:10.1029/2011GL050310.

Zitellini, N., Rovere, M., Terrinha, P., Chierici, F., Matias, L., 2004. Neogene through Quaternary tectonic reactivation of SW Iberian passive margin. Pure Appl. Geophys. 161, 565-587.

Zitellini, N. et al., 2009. The quest for the Africa-Eurasia plate boundary west of the Strait of Gibraltar. Earth Plant. Sci. Lett. 280, 13-50, doi:1016/j.epsl.2088.12.005.

Zoback, M. L., 1992. Stress field constraints on intraplate seismicity in eastern North America. J. Geophys. Res. 97, 11,761-11,782, doi:10.1029/92JB00221. 
Grevemeyer et al. Mantle earthquakes beneath the South Iberia continental margin and Gulf of Cadiz J. Geodynamics, 99, 39-50, 2016 http://dx.doi.org/10.1016/j.jog.2016.06.001 (accepted manuscript)

Tabell 1: Focal mechanism derived from first motion polarities

\begin{tabular}{lllllcc} 
Date & Time & Latitude & Longitude & Depth $(\mathrm{km})$ & Magnitude & strike/dip/rake \\
\hline 2010/01/26 & $05: 8$ & 35.961914 & -8.624268 & 17.0 & 2.4 & $118 / 30 / 90$ \\
$2010 / 02 / 27$ & $08: 13$ & 6.514486 & -8.865356 & 27.5 & 3.6 & $186 / 76 /-27$ \\
$2010 / 03 / 05$ & $17: 10$ & 36.079102 & -8.609619 & 34.0 & 3.6 & $85 / 34 / / 90$ \\
$2010 / 04 / 08$ & $14: 51$ & 35.899251 & -7.666626 & 39.9 & 2.8 & $124 / 18 / 90$ \\
$2010 / 05 / 02$ & $14: 08$ & 36.704102 & -9.498291 & 17.4 & 3.0 & $355 / 81 /-70$ \\
$2010 / 05 / 18$ & $10: 52$ & 36.239827 & -8.550110 & 37.4 & 3.0 & $275 / 27 / 85$
\end{tabular}




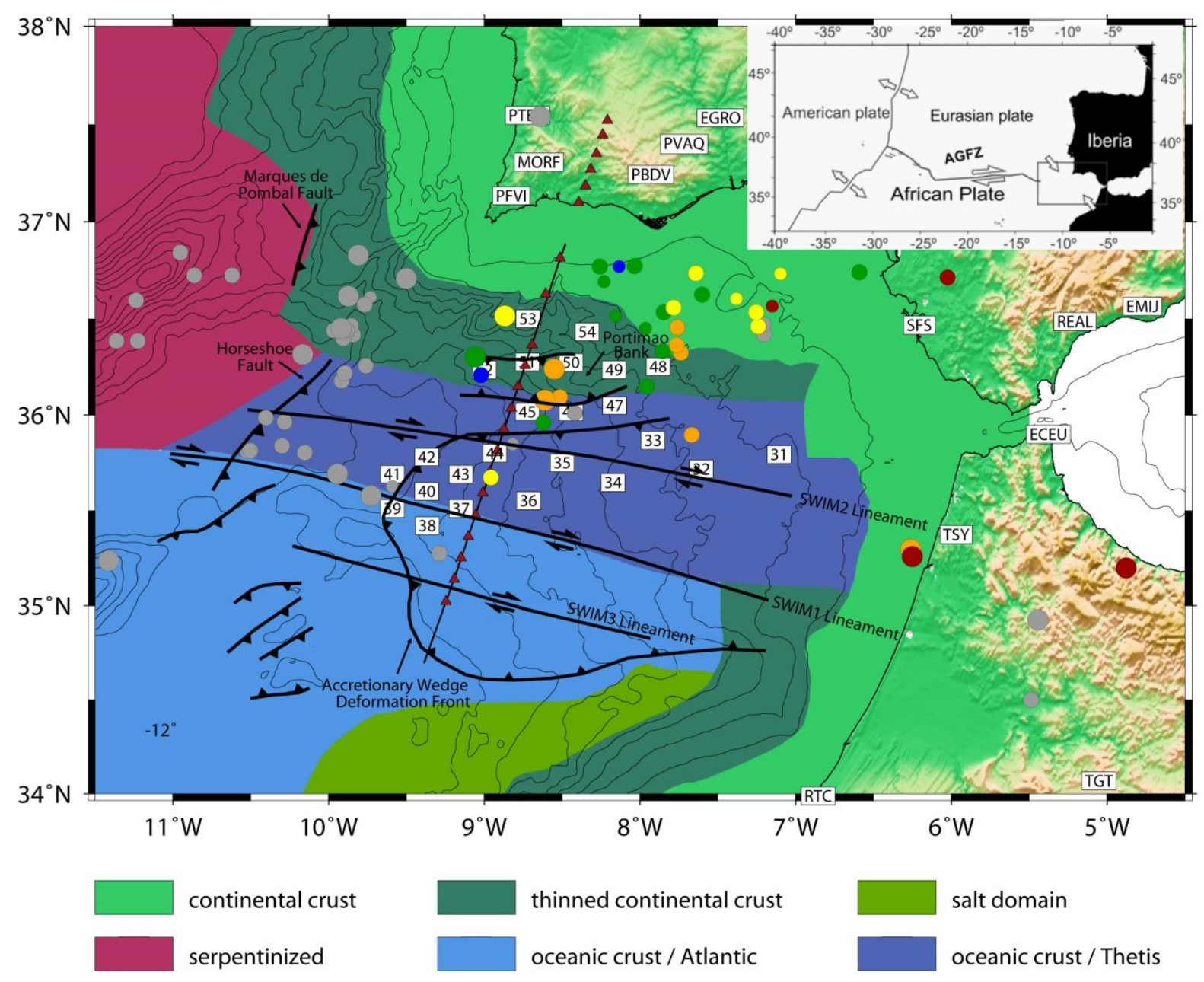

Figure 1. Deployment of an amphibious onshore-offshore seismological network in the Gulf of Cadiz, Iberia and Morocco. Colour coded offshore domains are geological units as defined by MartinezLoriente et al. (2014). Tectonic features are from Duarte et al. (2011). Numbered squares are TOPOMED ocean-bottom-seismometers (OBS) and labelled squares are permanent seismic stations deployed in Portugal, Spain and Morocco. Coloured dots are earthquakes coded by depth and quality. Grey dots are earthquakes with a gap $>200^{\circ}$. Blue: depth $z<5 \mathrm{~km}$; green: depth $5<z<15 \mathrm{~km}$; yellow $15<z<30$; orange $30<z<50 \mathrm{~km}$; red $z>50 \mathrm{~km}$. Thin black line and triangles mark the seismic line and seismic stations of Sallares et al (2011), shown in Figure 7. Plate motions (inset) are from DeMNets (2010). 




Figure 2. : Same as Figure 1 but with bathymetry from the Gulf of Cadiz (Zitellini et al., 2009). Numbered squares are OBS and labelled squares are permanent seismic stations. Epicentres are coloured as in Figure 1. In addition, focal mechanisms are shown. 


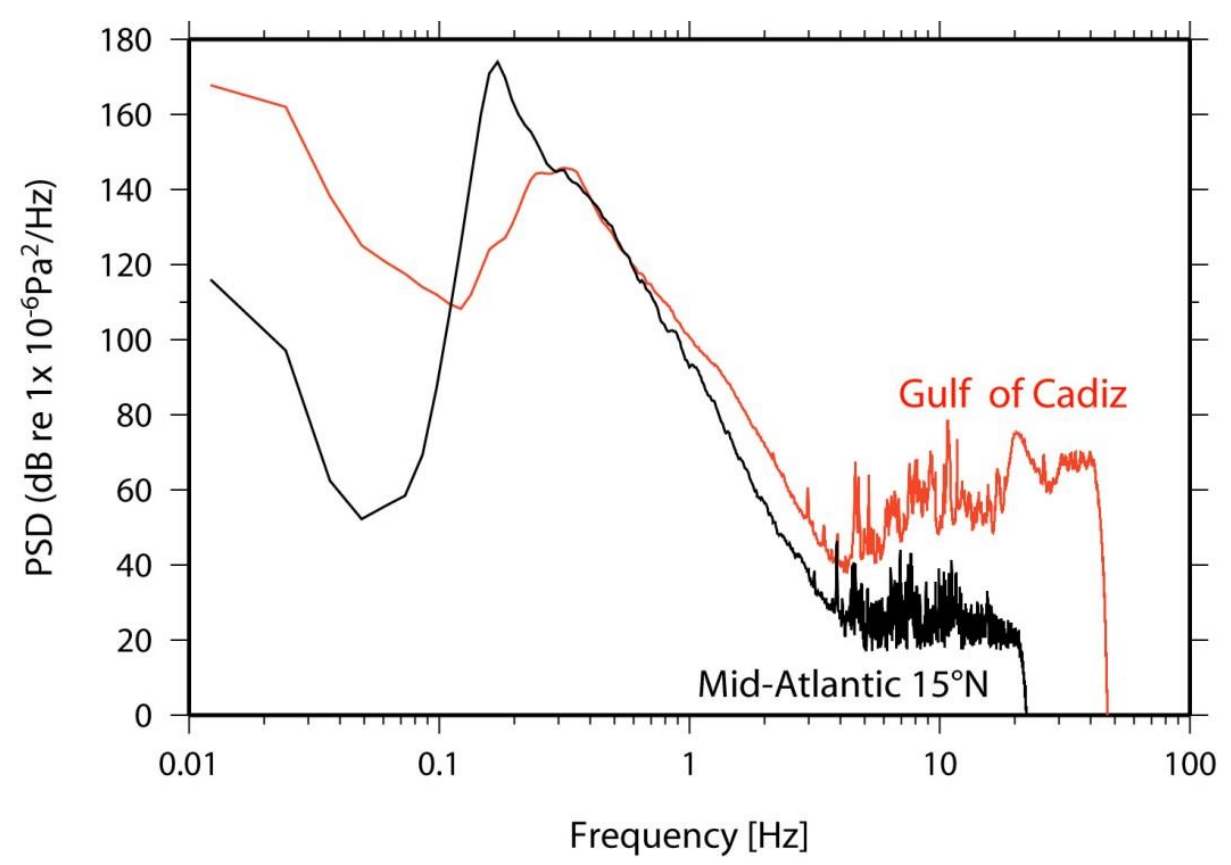

Figure 3. Power Spectral Density (PSD) of OBS36 (red line) in the Gulf of Cadiz and an OBS deployed at the Mid-Atlantic Ridge (MAR) near $15^{\circ} \mathrm{N}$ (black line). Note the much higher noise level observed in the Gulf of Cadiz. It might be reasonable to suggest that strong noise from ship's traffic affected seismic recordings, resulting in a much lower detection of small earthquakes with respect to quieter settings. OBS from the MAR is from Grevemeyer et al. (2013). 


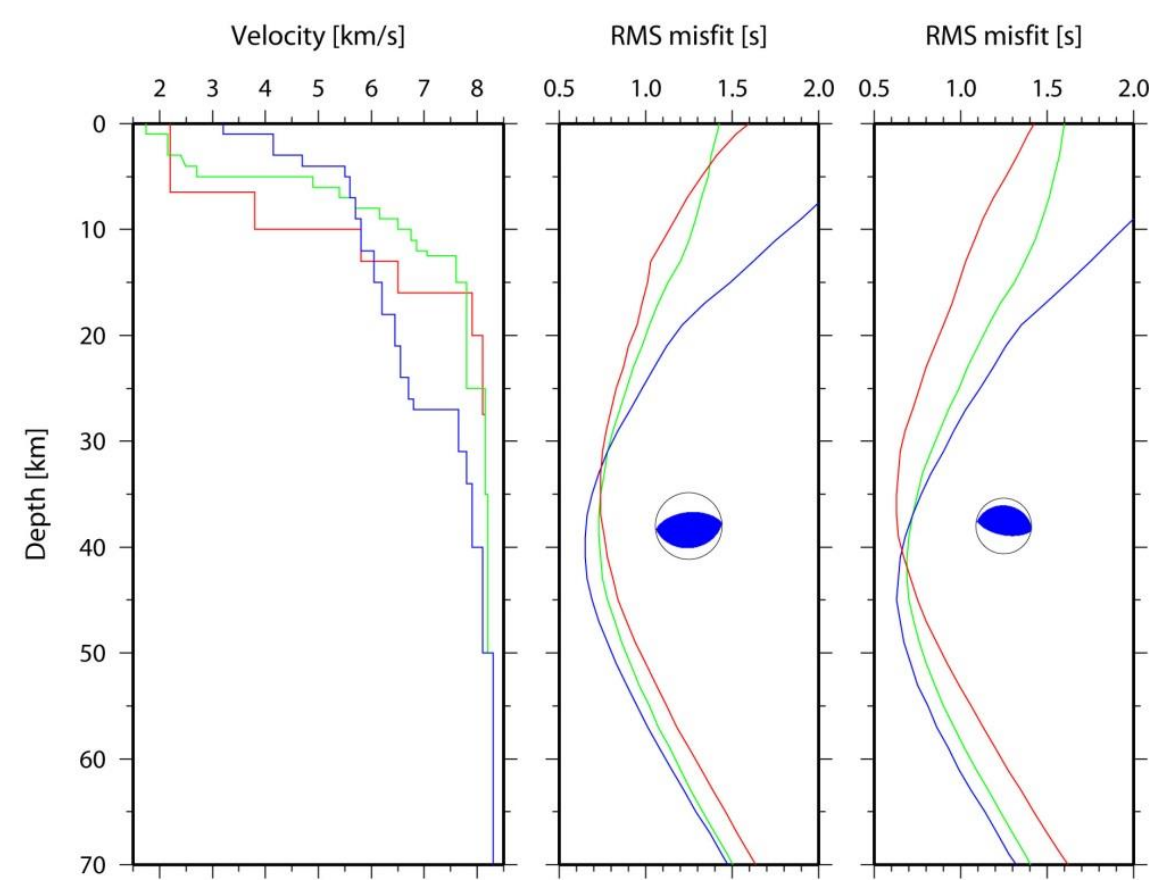

Figure 4. a) Seismic velocity-depth functions used to yield location and focal depth utilizing HYPOCENTER (Lienert et al., 1986; Lienert and Havskov, 1995). Red: model G-16 of Geissler et al. (2010), Green: model OBS-prism, and Blue: model OBS-Portimão (see text for discussion). b) rms misfit of the $\mathrm{Mw}=3.65$ th March 2010 thrust earthquake, Portimão Bank; c) rms misfit of the $\mathrm{Mw}=2.9$ 18th May 2010 thrust earthquake, Portimão Bank. 
a)
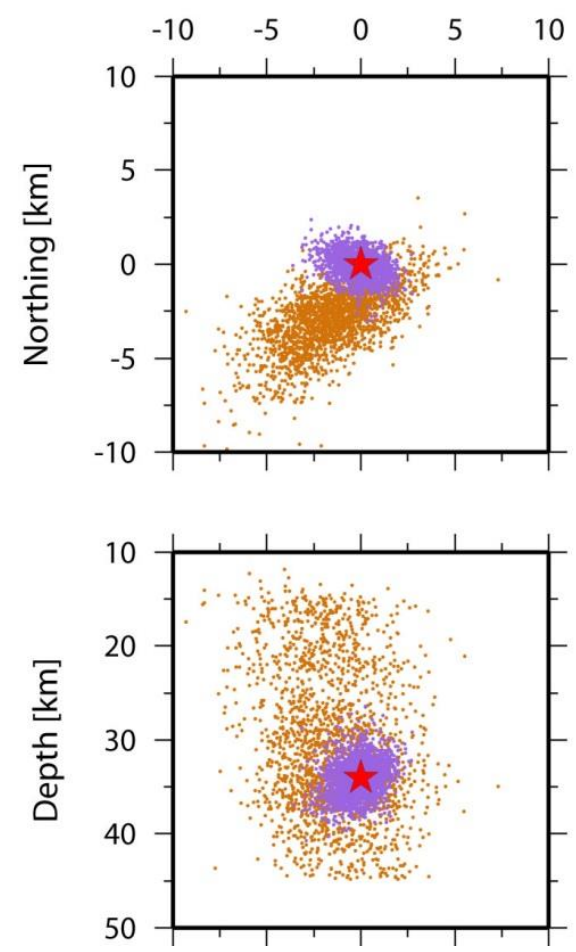

b) Westing $[\mathrm{km}]$
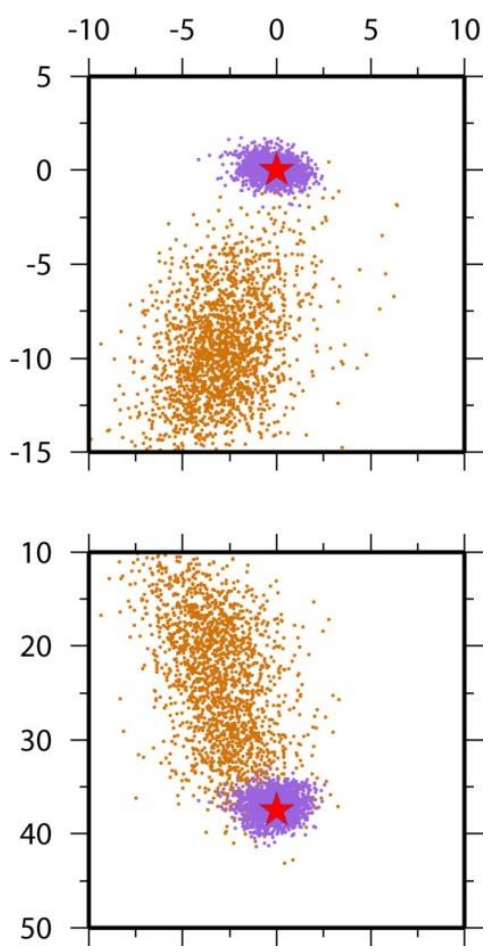

Figure 5: Plot of the Probability-Density-Function (PDF) of two thrust earthquakes in the vicinity of the Portimão Bank located with the velocity model G-16 using NonLinLoc. a) Mw=3.6 mantle earthquake of 5th March 2010, b) Mw=2.9 mantle earthquake of 18th May 2010. Light blue: probability density function (PDF) using all stations; orange: PDF locating events without offshore OBS stations. 


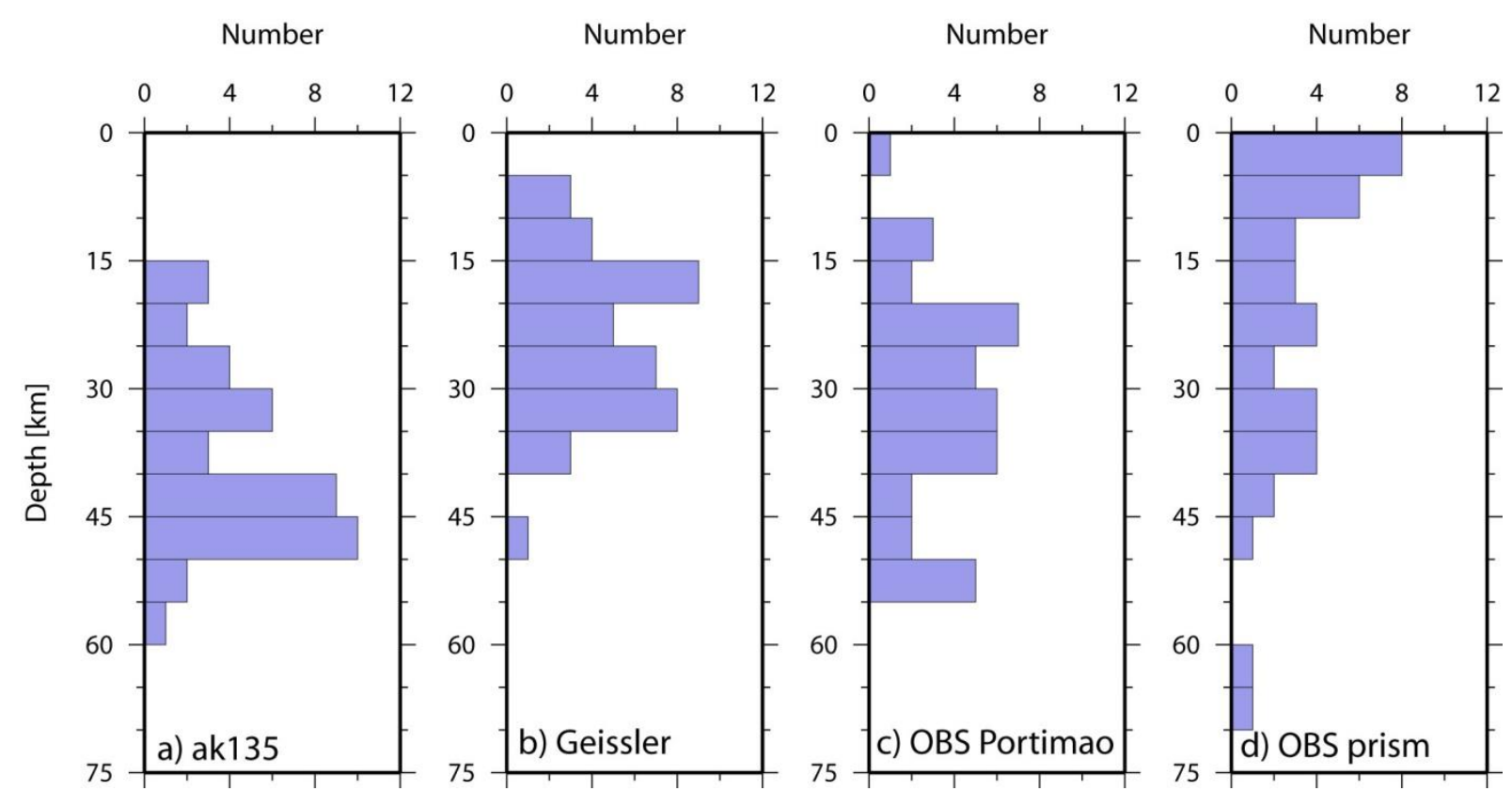

Figure 6. Histograms of depth distribution of all located events as a function of the velocity depth model used for relocations: a) Global model ak135 (Kennett et al., 1995), b) Model G-16 of Geissler et al. (2010), c) Model OBS-Portimão, representing seismic structure of the Algarve coast (Sallares et al., 2011), d) OBS-prism, representing seismic structure of the central Gulf of Cadiz (Sallares et al., 2011). 


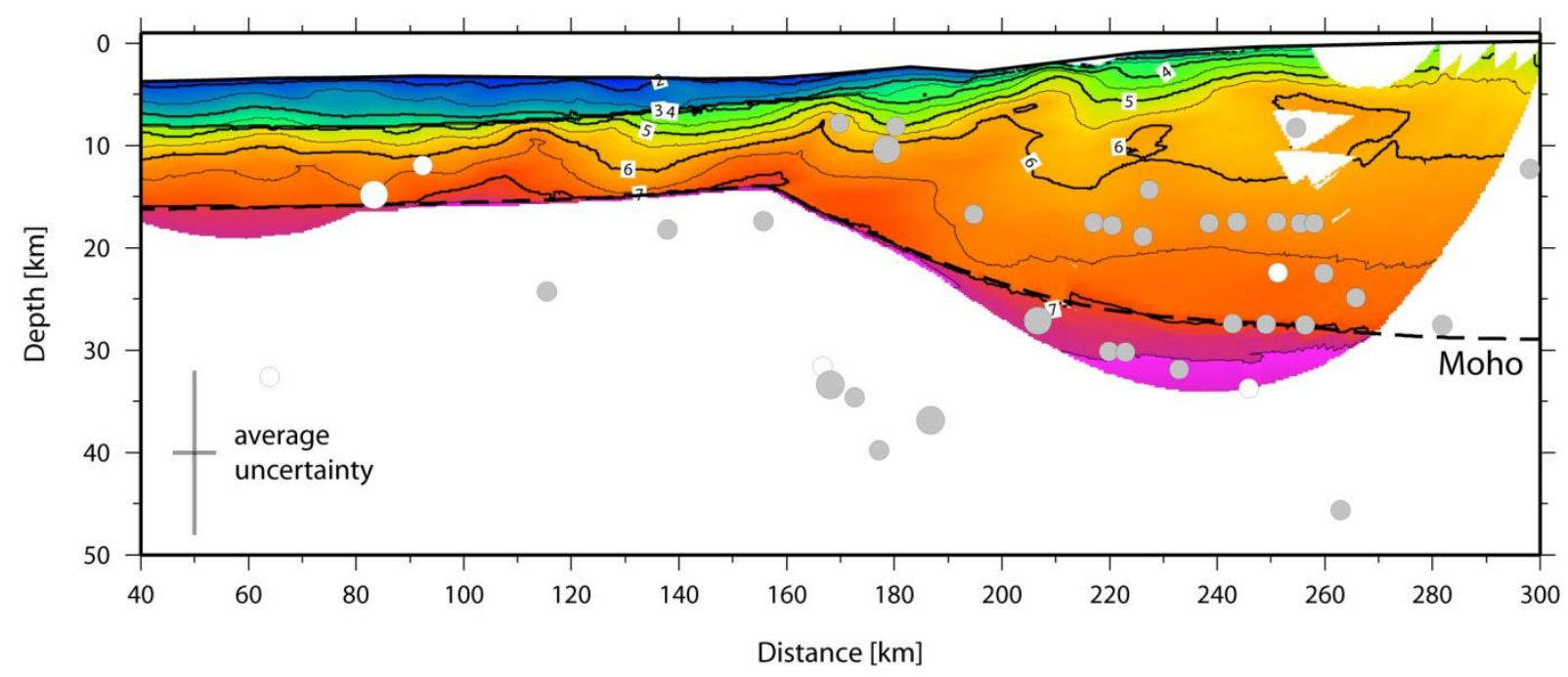

Figure 7.Colour-coded seismic velocity model (Sallares et al., 2011) of the South Algarve margin and Gulf of Cadiz (see Figure 1 for location). Grey dots are earthquake hypocentres projected onto the profile, white dots have a gap $>200^{\circ}$. Earthquakes were located with LinLinLoc using the velocity model G-16. 
a)

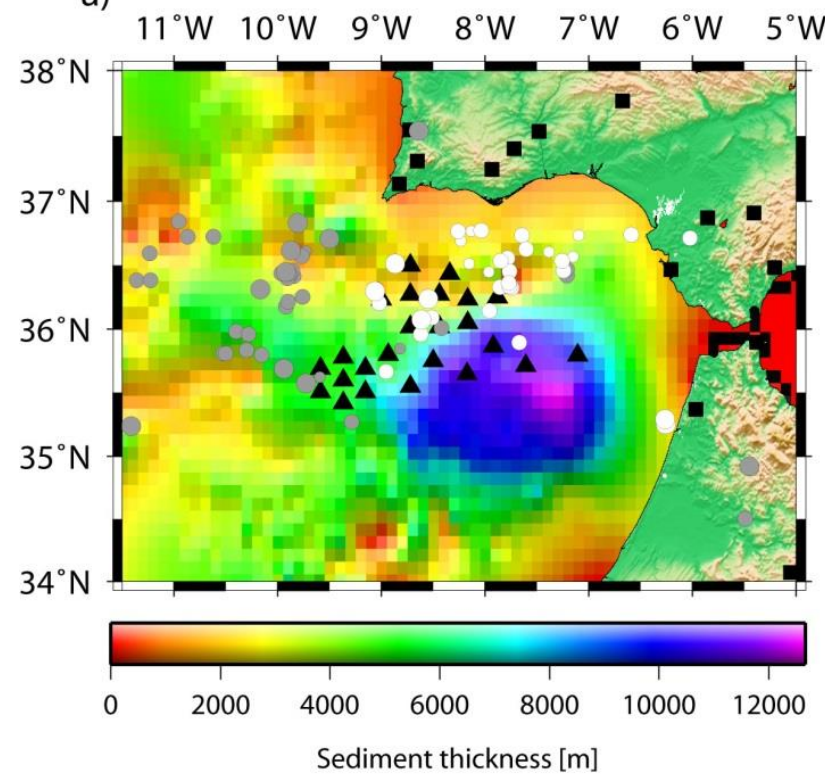

c)

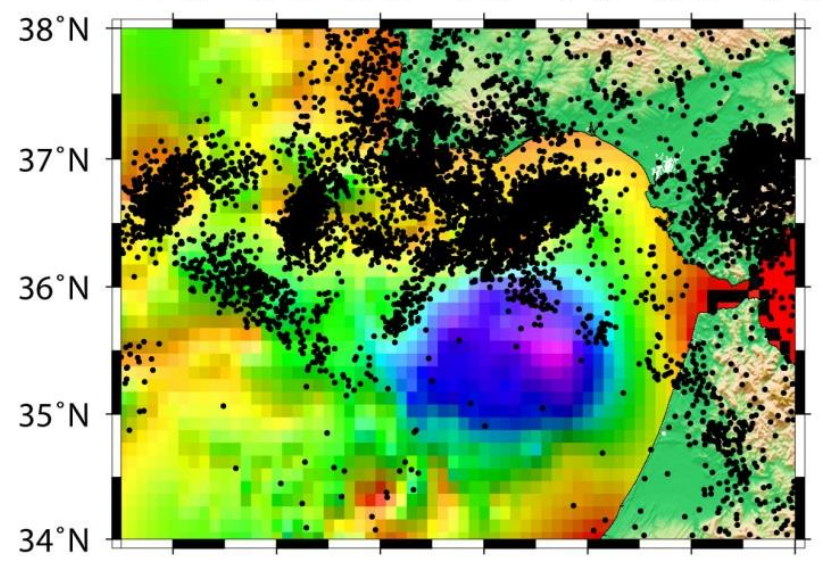

b)

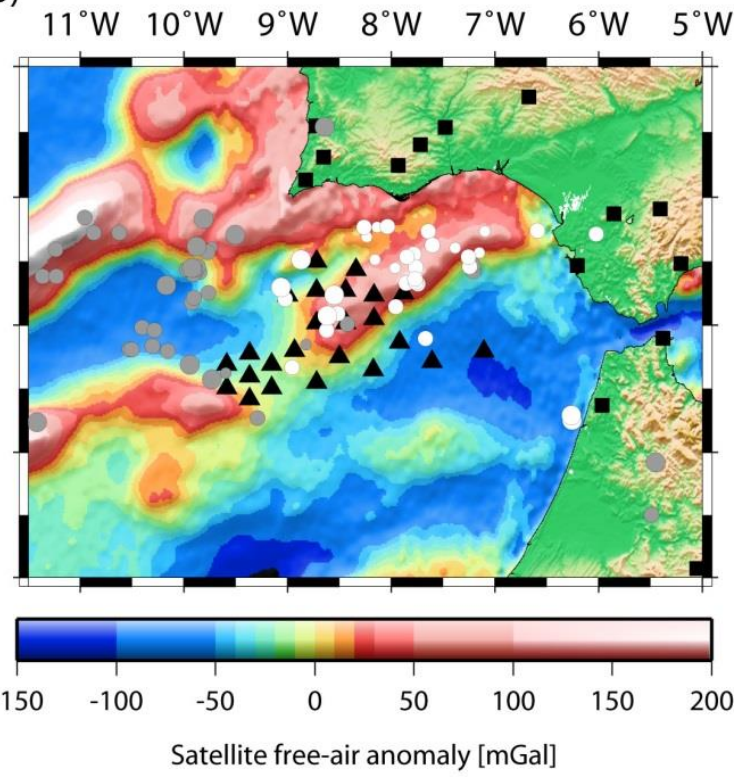

d)

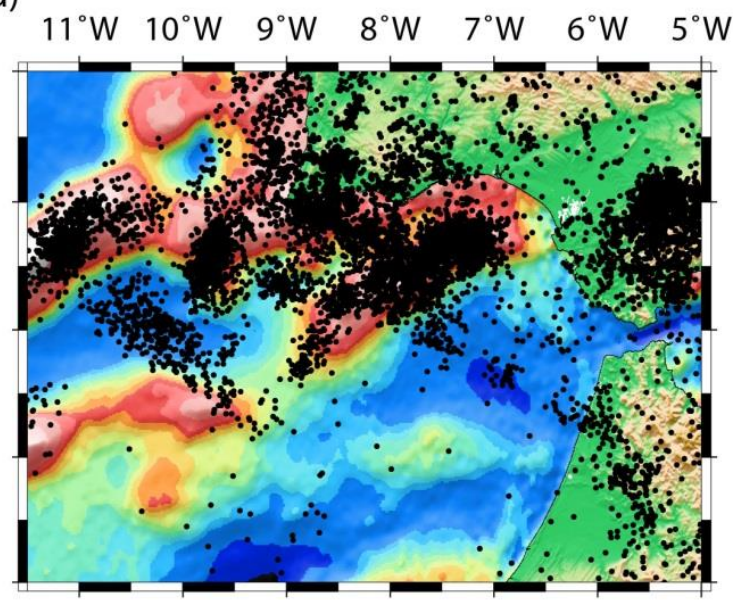

Figure 8. Relationship between sediment thickness, gravity field anomaly and seismicity. a, b) show seismicity recorded during our deployment; black dots have a gap $<200^{\circ}$, grey dot have a gap $>200^{\circ}$, c, d) is seismicity (2000-2015) from the IPMA catalogue. a, c) Sediment thickness (Thiebot and Gutscher, 2006) and b, d) gravity field (Sandwell et al., 2014) over the Gulf of Cadiz. 

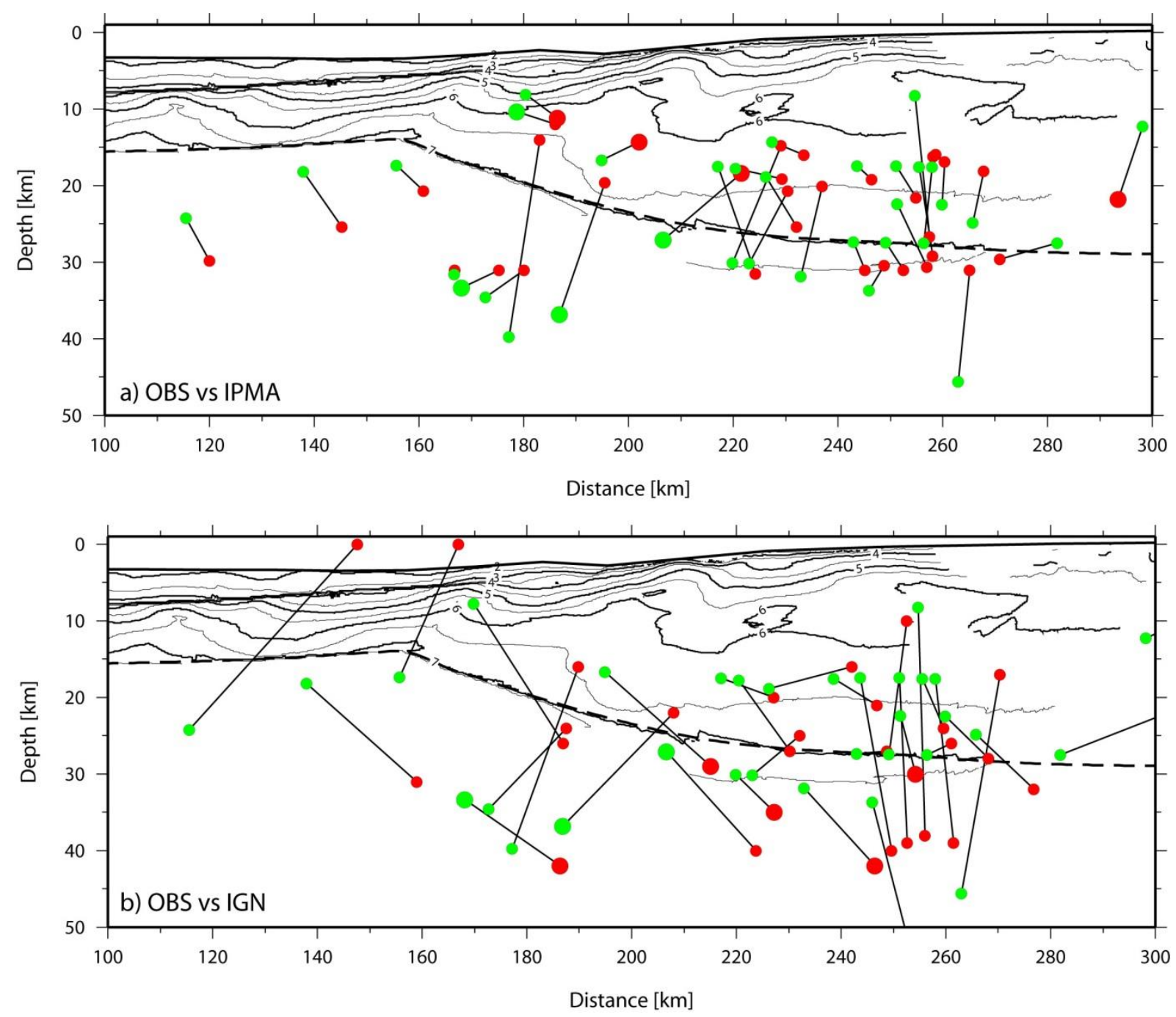

Figure S1. Location bias of hypocentres reported in regional catalogue data (red) with respect to our assessment (green, G-16). a) Portuguese IPMA catalogue, and b) Spanish IGN catalogue. Structural model is from Sallares et al. (2011). 


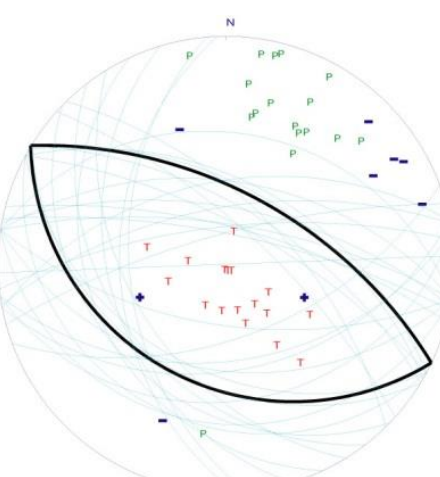

20101261058 1.4L 35.971-8.591 23.52.4MW

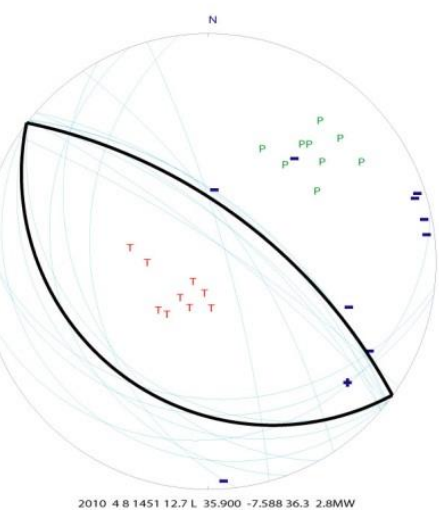

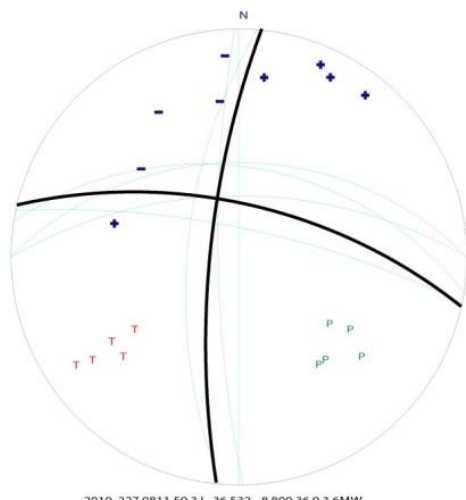

$9.3 \mathrm{~L} 36.532-8.80036 .93 .6 \mathrm{MW}$

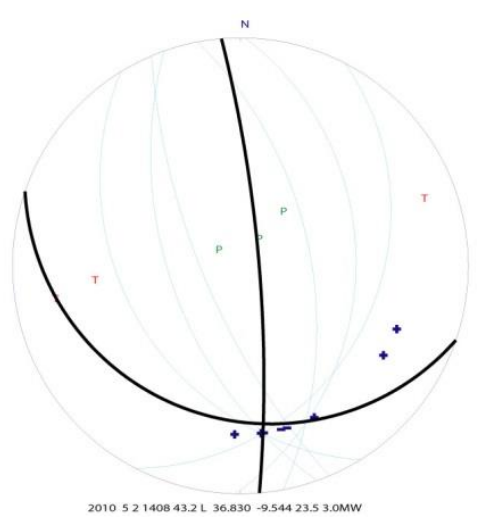

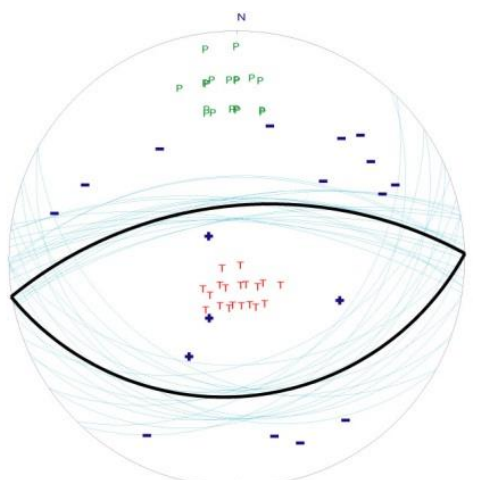

$201035171048.6 \mathrm{~L} 36.087-8.548449 .93 .6 \mathrm{~mW}$

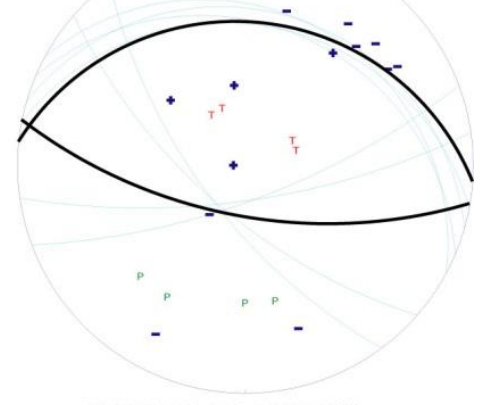

Figure S2. Focal mechanisms from first motion polarities 

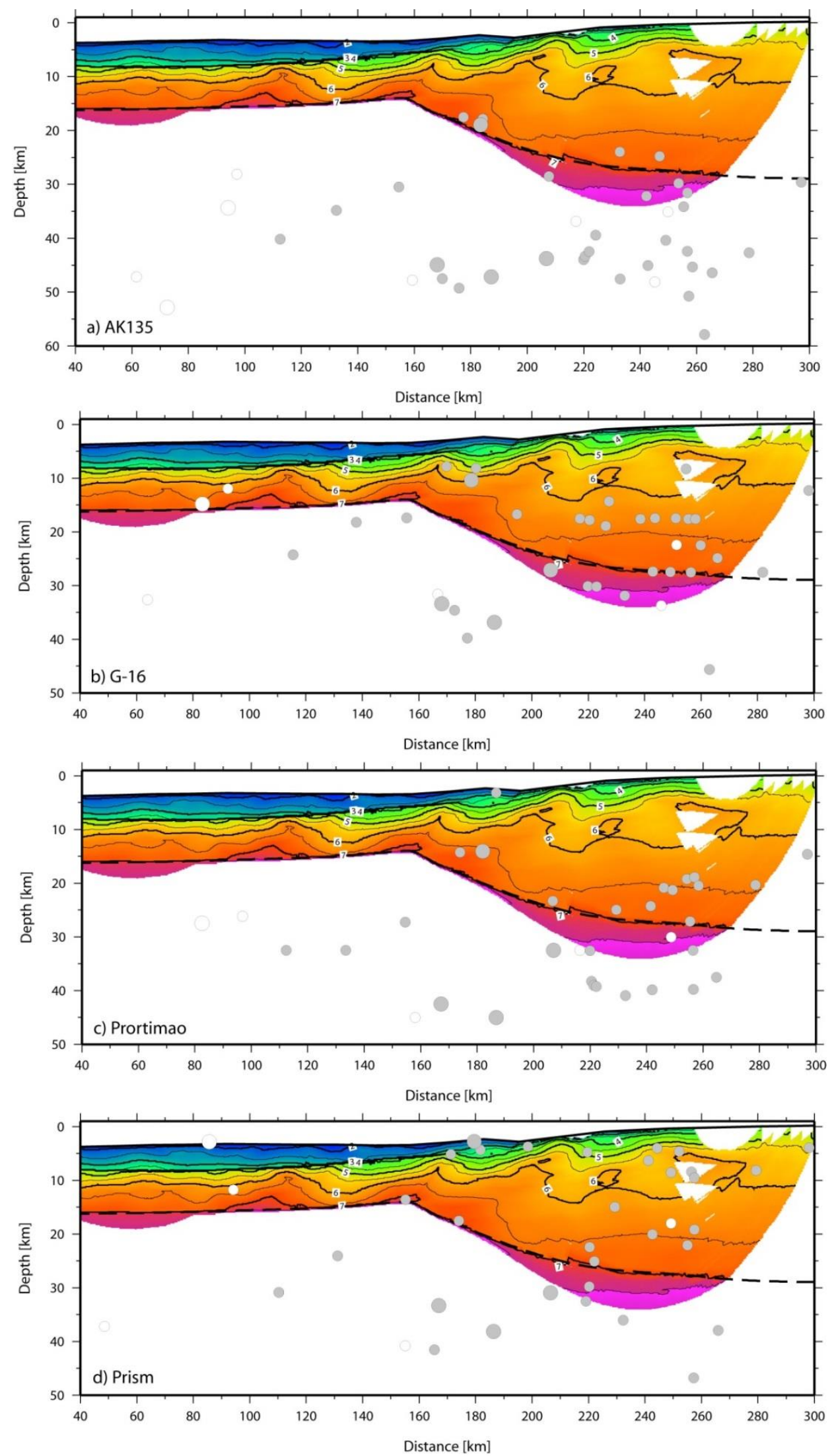

Figure S3. Same as Figure 7 but for all velocity models. Model is from Sallares et al. (2011). 